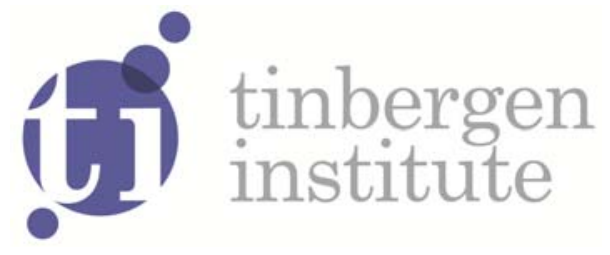

\title{
A Structural Equations Model for Assessing the Economic Performance of High-Tech Ethnic Entrepreneurs
}

Mediha Sahin'

Alina Todiras ${ }^{\prime}$

Peter Nijkamp

Bart Neuts ${ }^{2}$

Christiaan Behrens ${ }^{\prime}$

\footnotetext{
1 Faculty of Economics and Business Administration, VU University Amsterdam;

2 KU Leuven, Belgium;

3 Tinbergen Institute, The Netherlands.
} 
Tinbergen Institute is the graduate school and research institute in economics of Erasmus University Rotterdam, the University of Amsterdam and VU University Amsterdam.

More TI discussion papers can be downloaded at http://www.tinbergen.nl

Tinbergen Institute has two locations:

Tinbergen Institute Amsterdam

Gustav Mahlerplein 117

1082 MS Amsterdam

The Netherlands

Tel.: +31(0)205251600

Tinbergen Institute Rotterdam

Burg. Oudlaan 50

3062 PA Rotterdam

The Netherlands

Tel.: +31(0)10 4088900

Fax: $+31(0) 104089031$

Duisenberg school of finance is a collaboration of the Dutch financial sector and universities, with the ambition to support innovative research and offer top quality academic education in core areas of finance.

DSF research papers can be downloaded at: http://www.dsf.nl/

Duisenberg school of finance

Gustav Mahlerplein 117

1082 MS Amsterdam

The Netherlands

Tel.: +31(0)20 5258579 


\section{A Structural Equations Model for Assessing the Economic Performance of High-Tech Ethnic Entrepreneurs}

Mediha Sahin*

Dept. of Regional Economics

VU University Amsterdam

msahin@feweb.vu.nl

\author{
Alina Todiras \\ Dept. of Regional Economics \\ VU University Amsterdam \\ todiras.alina@gmail.com
}

\author{
Peter Nijkamp ${ }^{1}$ \\ Dept. of Regional Economics \\ VU University Amsterdam \\ pnijkamp@feweb.vu.nl
}

Bart Neuts ${ }^{\star \star}$
Flemish Centre for Tourism Policy Studies
K.U.Leuven
bart.neuts@ees.kuleuven.be

\author{
Christiaan Behrens ** \\ Dept. of Regional Economics \\ VU University Amsterdam \\ cbehrens@feweb.vu.nl
}

${ }^{1}$ Tinbergen Institute, The Netherlands

\section{Abstract}

In this paper we develop and test a conceptual model of the key relationships concerning the business performance and success of ethnic entrepreneurs. To that end, an explanatory modei'GALAXY' is presented which serves as a framework for mapping out the impact that various background factors are assumed to have on the economic performance of ethnic entrepreneurs active in the high-tech sector in four big cities in the Netherlands. The model describes the behavioural and other factors which are grouped into four components: Motivational Factors; Socio-economic Contextual Factors; Policy Factors; and Business Environment. After a first examination of the relationships using ordered logit modelling, the resulting structural equation model is tested by using the AMOS software. The information base of our research comes from a set of extensive survey questionnaires administered to migrant and native entrepreneurs in Amsterdam, Rotterdam, Utrecht and The Hague. With the help of these data, a series of hypotheses on the relationships between the above-mentioned four components and individual firm performance is tested, with particular reference to the success conditions of ethnic entrepreneurs in the high-tech sector. Our structural equation model shows that three of the eight hypothesized paths were statistically significant. Of the three significant paths, only the paths between social networks and pull factors had the direction predicted, while current business location and Business Performance showed a reverse relationship.

Key words: migrant entrepreneurship,GALAXY model, ethnic diversity,economic performance

JEL classification codes: L 26,R 11

${ }^{*}$ Corresponding author

${ }^{\star *}$ Co-authors 


\section{The Age of Migration}

\subsection{Introduction}

Global migration is increasing at a fast pace; nowadays approximately 3 per cent (215 million) of the world's population live outside their country of origin (Ratha et al., 2010). While European international migration flows have not increased considerably, at the same time regional mobility inside the European Union is much higher. The main determinants for individuals to relocate to another country are: the unemployment rates, differences in wages, cost of living, provision of public goods and public transfers, costs of moving, and also psychological costs, social networks, etc. (Zaiceva and Zimmermann, 2008; de Haas, 2010). Moreover, the migration propensity also depends on individual human characteristics, with migration decreasing with age and individuals with a higher education having a higher propensity to migrate (de Haas, 2010). Previous studies show that the earliest migrants are usually not those from the poorest regions, as presumed, but those from upper-lower to middle-income countries (de Haas, 2010).

The revolutionary technological and infrastructural developments in recent decades have dramatically changed the migration interface, allowing for the acceleration and transformation of the globalization process. It is especially the latest transportation and telecommunication technologies which have facilitated the upsurge of flows of people, goods, services, knowledge, capital, etc., and which have created opportunities for migrants to maintain transnational ties (de Haas, 2010). According to Coniglio (2008), 'immigration is extremely important in boosting the efficiency of European labour markets and increasing productivity, and in turn, competitiveness', and this author argues that strict immigration policies can create considerable distortions and damage to European labour markets. The positive effects of immigration are: (i) increased productivity; (ii) increase of the population of working age; (iii) boosting of trade; and (iv) increased variety of goods and services available in destination countries (Coniglio, 2008).

Most recently, the migration patterns were affected by the 2008 global financial downturn in a number of ways. Migrants, as a vulnerable layer of the host societies, were thus exposed to higher levels of anxiety and depression. Wright and Black's (2011) study provides an extensive overview of the impacts of the recent crisis on migration outcomes both on the micro- and the macro-level. At the macro-level, the downturn has led to a reduction of welfare spending and the toughening of international migration policy in some host societies. Furthermore, this context has provoked anti-immigration debates which has resulted in greater hostility, marginalization, and discrimination against migrants (Wright and Black, 2011). Another outcome has been an increase of the unemployment rate, especially in some industries such as construction, which has subsequently led to a significant reduction in the remittances that form a great part of the developing countries GOP, as well as being a far more effective instrument for poverty alleviation, income redistribution, and economic growth than the bureaucratic development programmes or development aid (Kapur, 2003). Moreover, at the micro-level, the global downturn has caused numerous tensions in migrant households, among which marital breakdown, increased pressure on women to send remittances, gender-based dietary changes (poverty being more likely to affect women), etc. (Wright and Black, 2011). However, according to Wright and Black (2011), the 2008 global downturn could be regarded as an opportunity for host societies to rethink their policy responses to international migration, thus, for instance, making a shift from a migration regulation approach toward development and poverty reduction strategies.

The issue of migration has numerous aspects worth addressing; however, this paper mainly focuses on the impact of migration on entrepreneurship. Since a large share of the cross-border mobility is due to labour-seeking activity, self-employment might become a necessity when employment opportunities are limited. This increased labour mobility in the Western world has led to a shift from employee labour contracts to self-employment labour contracts (Ibrahim and Galt, 2011). Ibrahim and Galt (2011) argue that a proportion of any minority group will 
become self-employed due to 'the changing structure of industries, the development of new industries and the shift to external contracting through markets rather than within organizations'. Wang (2010) finds that migration has boosted migrant business formation in a number of ways, among which, from a market perspective, it has expanded the demand for ethnic products, thus encouraging ethnic businesses that supply exotic products and services. Furthermore, immigration has led to the transformation of the institutional environment that influences the formation and development of ethnic firms. Some governments encourage such entrepreneurial activity, regarding it as a thrust for economic growth and a contributor to solving labour market imbalances in the receiving countries (Baycan-Levent and Nijkamp, 2009; Ibrahim and Galt, 2011). In Europe the share of migrant business ownership is expected to continue growing, and in some countries the rates of self-employed immigrants are exceeding those of the native-born population (Baycan-Levent and Nijkamp, 2009).

\subsection{Migrants in business: A world of opportunity}

Migrant entrepreneurs are having an increasingly strong impact on the economies of cosmopolitan cities, being an important driving force for economic growth in many US cities. They have made decisive contributions to the US economy for more than a century (Bowles and Kotkin, 2003). The US Census since 1880 shows that immigrants have been more likely to be self-employed than the native-born population, as mentioned above (Bowles and Kotkin, 2003). The boom in immigrant entrepreneurship is also a big phenomenon in Europe. Across the EU, immigrant entrepreneurs are contributing greatly to the European economy, and display a strong capacity and potential for entreweneurship (Tzilivakis, 2005). In 2000, the 16 million legal immigrants in Western Europe earned more than $\$ 460$ billion. The number of immigrant entrepreneurs in the EU has increased by about 20 per cent over the past seven years. In the Netherlands, the number of businesses owned by foreigners has tripled since 1986. Research on migrant entrepreneurship has recently been dominated by the study of self-employment, ethnic enclaves, mixed embeddedness, and transnationalism. This literature argues that the foreign-born are more likely to start companies than the native-born (Fairlie, 2008; Light and Rosenstein,1995). Immigrants have a much higher rate of self-employment than the general population (Light and Bonacich, 1988). Hence, governments in a growing number of countries are taking an active role in promoting entrepreneurship, and are counting on the help of entrepreneurs in creating businesses, and thus providing jobs.

An entrepreneur is a person who is able to act with self-confidence, a leader who shakes existing norms and patterns. In addition, he or she is the person who takes initiatives, accepts risks or failures, and manages resources, materials, and personnel to create value for customers (Hisrich and Peters, 1989). Richard Cantillon observed that an entrepreneur is one who bears the risk of buying and selling products or goods; he is a risk taker who buys products at a certain price and then sells them at an uncertain price,therefore taking a risk. According to Meredith et al. (1982) and Makhbul (2011), entrepreneurs are individuals who have the capability to foresee opportunities, gather the needed resources - time, energy, and money - and take the necessary actions to ensure success. Finally, according to Kuratko and Hodgetts (2004), entrepreneurship is a process of creation and innovation with four dimensional elements - individual, organization, environmental factors, and process, with support from the government, education, and constitution. Entrepreneurs are often driven by passion and opportunity. The reasons for choosing the entrepreneurial lifestyle include the desire to be independent and to be passionate about work, to achieve satisfaction, and to find a motivation for productivity (Minetti et al.,2006).

Apart from these pull factors that focus on the positive attributes of self-employment, which makes it an attractive enterprise entered into by choice alone (de Freitas,1991), the motivation to enter self-employment can also be related to push factors (Baycan-Levent et al., 2003; de Freitas, 1991). According to Portes and Rumbaut (1996), push factors are the ones that obstruct entry or block opportunities to pursue normal employment in the primary job market,thus forcing new immigrants into self-employment. 


\subsection{The socio-economic impact of migrant entrepreneurs on the receiving countries}

Migrant entrepreneurship plays a central role for the economic development of the receiving countries mainly through the creation of job opportunities for other immigrants who would otherwise be excluded from the mainstream labour market. Moreover, it can consequently reduce the competition with the natives in the labour market (Chrysostome and Lin, 2010).

The rationale behind the self-employment of immigrants can be, according to Chrysostome and Arcand (2009\}, driven by either necessity or by opportunity. Migrant entrepreneurs in the former category are usually middle-aged men coming from developing countries, with a relatively low educational level, insufficient professional experience, and a reliance on social networks as their primary source of information, labour, and start-up capital. On the other hand, the entrepreneurs in the latter category are known to be highly-educated, less/not reliant on ethnic networks, and more proficient in host country's language. They target the mainstream markets and have access to financial institutions in the receiving country (Chrysostome and Arcand, 2009).

According to Chrysostome and Lin (2010), among the most prominent non-economic impacts of migrant entrepreneurs are: the development of ethnic communities; migrants' social integration and recognition; encouragement of entrepreneurial spirit; and the creation of role models for migrants. Moreover, migrant entrepreneurship contributes to the formation of social capital (Zou and Kim, 2006).

Curci and Mackoy (2010) distinguish three levels of migrant entrepreneurs' integration into the host society: 1) the low level, which is highly segmented and supplies the ethnic market with ethnic products; 2) the middle level, which can be product-integrated (mainstream products for the ethnic market) or market-integrated (ethnic products for the mainstream market); and 3) the high level, which targets the dominant market with a mainstream product.

Moreover, an important aspect of migrant entrepreneurship treated in the literature is that of the effects of returnee entrepreneurs on their home country's high-tech firms. Filatotchev et al. (2011) define the returnee entrepreneurs as 'scientists and engineers returning to start up a new venture in their native countries, after several years of business experience and/or education in OECD countries'. These authors (Filatotchev et al., 2011) have found that the returnee entrepreneurs can generate knowledge spillover effects that consequently stimulate innovation in local high-tech firms.

The study of Ndofor and Priem (2011) argues that first- and second-generation immigrant entrepreneurs' endowments of economic, human, and social capital, together with their degree of social identification with their ethnic community, affect their elemental strategic choice to pursue a venture strategy focused either on their ethnic enclave or on the dominant market. Therefore, the findings of Ndofor and Priem (2011) indicate that there is a strong connection between the social capital of the migrant entrepreneurs and the venture strategy they choose. It has been confirmed that the immigrant entrepreneurs' strong network ties with their ethnic community will encourage a ethnic enclave strategy. Subsequently, human capital has had a mixed effect on firm strategy. On the one hand, the entrepreneurs with previous managerial experience tended to pursue dominant market strategies, and, on the other hand, those with previous entrepreneurial experience pursued an enclave strategy. Furthermore, no connection was found between the economic capital and the venture strategy chosen (Ndofor and Priem, 2011).

The literature on immigrant entrepreneurship has predominantly focused on the first-generation migrants, with increased attention being paid to the markets they serve (in most of the cases, these markets arise within their own immigrant communities), their social networks, their mixed embeddedness, business characteristics, etc. At the same time, the literature on second-generation entrepreneurs is lagging behind, and it is important to shed some light on the entrepreneurship evolution of the latter group since it has some crucial distinct features when compared with the former group. A strong point of difference is the gradual move towards a mainstream clientele, and thus the second-generation is more likely than the first-generation to break out from their own ethnic 
boundaries where the competition is rather fierce and growth is constrained (Smallbone et al., 2005; Rusinovic, 2008). Another major point of distinction between the first- and the second-generation entrepreneurs is their sectoral choice. Previous studies have shown that first-generation entrepreneurs are predominantly active in the traditional industries (catering, hospitality, retail, etc.), often targeting their ethnic client base with an ethnic product. On the other hand, the following generation is increasingly shifting towards the high-tech sector, targeting a mainstream market with a mainstream product (see Baycan-Levent et al., 2009). Some explanatory factors for this evolution of immigrant entrepreneurship could be a better knowledge of the local language and environment, higher educational attainment, etc.

The aim of this paper is to assess the impact of several fundamental factors on the economic performance of second-generation migrant entrepreneurs, and to see if there is a significant relationship between Business Performance and the main determinant factors of our 'GALAXY' model. The structure of this study is as follows: We start with the theoretical background in Section 2, in which we introduce and give an overview of our novel framework 'GALAXY'. Subsequently, in Section 3, the methodology part, we discuss the hypotheses of this study, and the research design and approach used to test the hypotheses. In Section 4, we present the study methods and empirical results. Study methods used are ordinallogit regression and structural equation modeling and their application to our 'GALAXY' model. In the next section, we discuss the results of our empirical investigation. Finally, the last section concludes with concluding remarks.

\subsection{International positioning of the GALAXY model}

Empirical studies about the contributions of immigrant high-tech entrepreneurs have generally been restricted to particular countries or regions in countries. High-tech start-ups are founded by people who are able to recognize and exploit entrepreneurial opportunities \{Shane and Venkataraman, 2000). According to Hart and Acs (2011) the foreign-born have both advantages and disadvantages with respect to the native-born in high-tech entrepreneurship. Florida (2002) suggests that immigrant high-tech entrepreneurs recognize different opportunities than their native-born counterparts.

Kirzner (1973) claims that entrepreneurs are more 'alert' to opportunities than others. In the Kirznerian sense, immigrants may be more 'alert' than the native-born. 'Alertness' is difficult to measure, but there are other factors, which are also typical prerequisites for recognizing high-tech business opportunities, such as formal knowledge acquired from education and skills gained from work experience (Bullvaag et al., 2006). Hart et al. (2009) claim that, even though immigrant entrepreneurs are more alert, more knowledgeable, and more creative, they still face obstacles in recognizing high-tech opportunities that do not challenge most natives. Language proficiency in general is the most important determinant of immigrant success in the labour market (Borjas,1999). And the language barrier, for instance, may impede opportunity recognition.

Hart and Acs (2011) investigated high-tech immigrant entrepreneurship in the United States. Hart and Acs (2011) found that immigrants have played an important role in founding some of the nation's most important businesses. Immigrant enterprises operate in the same industries as their native-founded counterparts, are about the same size, and have about the same level of technological performance. In that study, three multivariate analyses are carried out that compare high-impact, high-tech firms that have at least one immigrant in their founding teams with those that were founded by native-born entrepreneurs. The authors (Hart and Acs, 2011) found that the two groups of firms are not significantly different with respect to economic and technological performance.

A study of Hart et al. (2009) on high-tech entrepreneurship among migrants in the US has identified important similarities and discrepancies between native-founded and immigrant-founded businesses. The commonalities and differences between the two founding groups are the size and the industries they operate in. The distinctive factor of the immigrant businesses is related to the location decision, in many cases these 
businesses decide to locate in those states where there are large immigrant groups. Yet another distinction concerns the existence of the companies' strategic relationships with foreign firms, which, according to the study of Hart et al. \{2009), are almost twice as probable in the case of migrant-founded firms.

\section{Theoretical Background:The GALAXY Model for Analysing the Performance of Ethnic Entrepreneurs}

\subsection{A systemic description: Entrepreneurial success and ethnicity}

Entrepreneurial success is complex and difficult to measure (Shane and Venkataraman, 2000). Moreover, the measurement of business success draws from different approaches (Sexton and Bowman-Upton, 1990), with each approach having different limitations in terms of evaluation, validity, reliability, availability, accuracy, etc. Therefore, entrepreneurial success has been defined in different ways. The easiest definition is through tangible elements, such as revenue or a firm's growth, personal wealth creation, profitability, sustainability, and turnover (Perren, 1999; Amit et al., 2000). Watson et al. \{1998) and Dafna 2008) associate entrepreneurial success with continued trading, and entrepreneurial failure with unrewarding or ceased trading. According to Bailom et al. \{2007), business success factors refer to: (a) profitability; $\{b$ ) growth; (c) advantageous market position with regard to quality, brands, etc.; and (d) subjective assessment by the most senior executives to ascertain how well the company is prepared for the competitive conditions and challenges of the future.

The literature on how businesses need to operate to achieve success relates to works on business survival, and growth in sales and profitability, as well as in growth in the size of the firm (Bates, 1990; Hall, 1992; Kalleberg and Leicht, 1991). Entrepreneurs with relatively higher levels of managerial performance- whether as a result of their managerial experience, education and training in management, or their personal traits- are likely to pursue entrepreneurial activities with potentially larger returns \{Bhide, 2000; Cassar, 2004). Both managing innovation, R\&D and change \{Chakrabarti, 1990; Deeds and Rothaermel, 2003) and networking (Anand and Khanna, 2000; Duysters et al., 1999; Walter et al., 2006; Dafna, 2008) are found to stimulate sales. The management practices of business owners have been repeatedly found to be positively associated with business success (Barney, 1991; 2001; Zahra, 2007). The entrepreneur's managerial performance (i.e. capabilities, personal abilities) is also associated with business growth (Barney,1991;2001), i.e. number of employees. Employees are a critical resource in the achievement and maintenance of any growth \{Bhide, 2000; Flamholtz and Randle, 2000; Greiner, 1998; Watson, 2006), and thus effective management of their employees enhances entrepreneurs' business success. Studies show that the most important managerial functions for achieving growth in the number of employees relate to effectively managing people in terms of empowerment, feedback, and personal development, and rewarding the employees (Weitzman and Kruse, 1990; Zenger, 1992).

Entrepreneurial factors that contribute to the success of entrepreneurs from previous studies refer, according to Say 1971), to the possession of outstanding qualities, especially in decision making, and the need for achievement (McClelland, 1961). Other outstanding qualities include an internal locus of control (Rotter, 1966), self-confidence, independence (Hisrich and Gracher, 1995), and innovativeness, as well as good communication and decision-making skills \{Cox and Jennings, 1995). An entrepreneur must also be able to face any situation effectively during the formation of a new venture. Risk taking is an important factor in developing a strong entrepreneurial personality, which is useful for business activities (Wadhaw, 1998). Other characteristics of successful entrepreneurs include high self-efficacy, opportunity recognition, perseverance, and social skills \{Markman and Baron, 2003). Hodgetts and Kuratko (1992) confirm that characteristics such as being creative and having good interpersonal, mental and technical skills, all contribute to an entrepreneur's success. In addition, being goal-oriented, pragmatic, determined, flexible, and self-confident are distinguished as attributes that add value to entrepreneurs $\{$ Nandram,2002). Another important factor that contributes to successful entrepreneurs is knowledge that is gained from various sources such as training, or personal experience through formal or informal 
education (Aldrich and Martinez, 2001). Leadership is also another pertinent factor that contributes significantly to business success (Dafna, 2008; Jong and Hartog, 2007). Entrepreneurs need two types of leadership competencies in order to succeed, including functional and self-competencies (Swiercz and Lydon, 2002). Functional competencies consist of four performance subsystems (i.e. operations, finance, marketing, and human resources), while self-competencies include intellectual integrity, promoting the company rather than the individual leader, utilizing external advisors, and creating a sustainable organization. Although there is a robust theory, for instance, on the relationship between entrepreneurial success and gender (Aisos et al., 2006; Boden and Nucci, 2000; Grilo and Irigoyen, 2006; Dafna, 2008), with most studies showing that women entrepreneurs are less successful in turning their managerial performance into successful and profitable enterprises (Carteret al., 1997; Du Reitz and Henrekson,2000), studies on entrepreneurial success and ethnicity are scarce.

In the last decade, a number of empirical studies have suggested that differences between the genders in managerial performance can be explained by cultural factors, such as nationality. Managerial performance has been found to differ across nationalities, both in terms of perceptions of what determines managerial performance, and in terms of management practices (Atuahene-Gima and Ko, 2001; Neelankavil et al., 2000; Steensma et al., 2000). The existing literature has revealed positive relationships between managerial functions related to innovation, business longevity (Gagnon et al., 2000) and turnover from sales (Chakrabarti, 1990; Deeds and Rothaermel, 2003); and that a greater focus on leading change (Chakrabarti, 1990; Deeds and Rothaermel, 2003) has also stimulated business turnover from sales.

Furthermore, the success of entrepreneurs is influenced by support from others, which can be both formal and informal support. Formal support comes in the form of financial, technology, and strategic partnerships or industrial contacts (Carrier et al., 2004), while informal support may come from personal and community-based networks (Baycan-Levent et al., 2003). Many other variables may contribute to the success or failure of businesses, and these may vary from business to business. Some examples of these variables refer to geographical location, prior experiences in entrepreneurial start-ups, and education and training level (Bruner, 2011). According to Bruner (2011), migrant businesses may have different variables that may contribute, or be a barrier, to success.

The odds of survival of migrant firms depend on multiple factors, among which are: psycho-behavioural factors (risk-taking propensity and commitment); ethno-cultural factors (ethnic networks, and ethnic market niche); financial factors (start-up capital and emergency loans); managerial factors (educational attainment and previous professional experience), and institutional factors (Chrysostome and Arcand, 2009). In a previous study we proposed a model: namely 'GALAXY', that identifies the factors that have a crucial impact on the Business Performance of business entrepreneurs. We included in our model factors ranging from the individual level to the macro-level. These are four main factors: the Motivational Factors, Business Environment, Socio-economic Contextual Factors, and Policy Factors (Sahin et al., 2011a,b).

There are three most significant Motivational Factors (MTF\}. The first is the entrepreneurial animal spirit that overcomes inaction caused by uncertainty. This trait is linked to the motivational pull factors (Baycan-Levent et al., 2003), and the opportunity-driven rationale (Chrysostome and Arcand, 2009). The second motivational characteristic which is rather important, especially in the case of the migrant entrepreneurs who are far more disadvantaged than the local entrepreneurs, is bounded rationality, which is based on an ecological rather than a logical view of behaviour (Gigerenzer, 2010). This characteristic will allow the entrepreneur to make decisions, disregarding such hurdles as risk and uncertainty, complexity, and incomplete information about alternatives (March, 1978). As such, bounded rationality is associated with motivational push factors (Baycan-Levent et al. 2003; Chrysostome and Arcand, 2009), since it encompasses cognitive limitations to entrepreneurial decision making. The third crucial motivational factor for migrant entrepreneurship is the migrants' social networks, since these networks provide access to financial and physical resources, information, and human capital, as well as 
helping to reduce their transaction costs (Rath, 2000; Johannisson, 2000; van Delft et al., 2000; Clark and Drinkwater, 2000; Aldrich and Waldinger,1990;Baycan-Levent and Nijkamp, 2009).

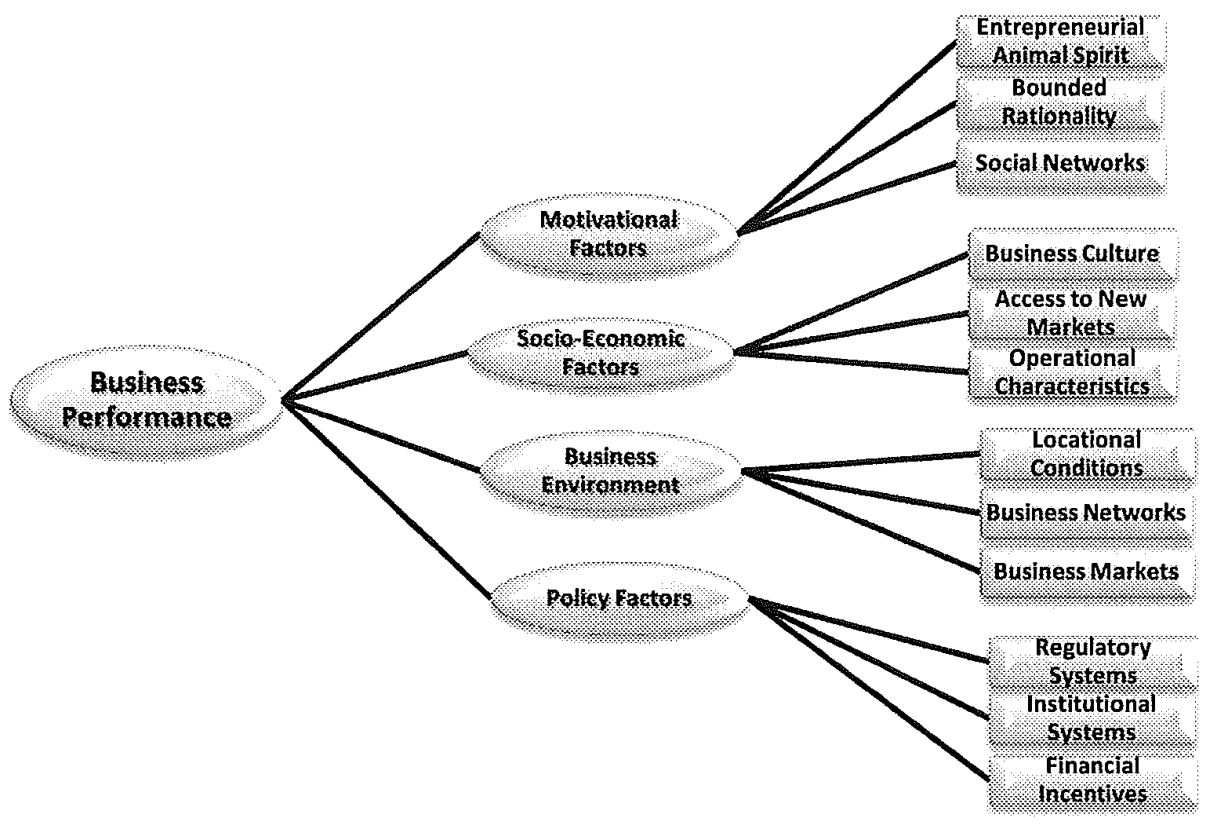

Figure 1: The main structure of the GALAXY model of migrant entrepreneurial performance

In the set of Socio-economic Factors (SEF\} we have included the business culture, which can have a considerable impact on the economic performance of enterprises. According to Casson \{1994), a strong business culture can reduce the transaction costs and increase performance. The other factor is access to markets, which in the case of immigrant enterprises is much more limited compared with the local enterprises. This could, on the one hand, be due to the limited knowledge of certain business environments, local language, limited skills, and the previous experience of the ethnic entrepreneur, or it could be the case that certain countries have policy measures that limit the access of immigrants to certain markets. Another factor here is the operational characteristics of the migrant enterprises, the most common being: low economies of scale; instability and uncertainty; and small or differentiated markets (Waldinger, 1986). However, these characteristics might differ when we analyse the migrant enterprises in the high-tech sector.

A third category of factors is the Business Environment (BEF\} of migrant-owned firms. Here, we include the locational conditions, which are very important and strategic both for native-owned firms and, sometimes to a greater extent, for the migrant-owned firms. The business networks (of venture capitalists, banks, accountants, creditors, lawyers, trade associations, etc.) of ethnic entrepreneurs also play an important role, but they are rather weak in the case of migrants (Marlow,1992). Previous research emphasizes that migrants in most of the cases rely on their informal networks at every stage of the new firm development. The business markets of migrant enterprises can be considered to be one of the main determinants of business survival and continued success. The customers, suppliers, and competitors can, all together, both stimulate or ruin the business. A last set of factors, the Public Policy Factors (PPF\}, comprise the institutional systems and the regulatory system which, in some countries, can facilitate and in others, on the contrary, inhibit the emergence of new industries and/or migrant- 
owned firms (Kloosterman and Rath, 2001). Financial incentives which are introduced by the government locally or nationally can contribute to ethnic-business formation and eventual business success. However, migrants seldom use these incentives, which could be due to limited knowledge about the availability of this governmental financial help or, in some cases, the bureaucracy characteristic of the provision of this assistance.

The impact of each of the factors in the GALAXY model on the economic performance of the migrant firms approached in the course of this study will be tested, and the results will be presented in this paper.

\section{Methodology}

This section describes the research methodology that was used for the study. The section begins with a description of the research design and data collection. It then presents the operationalization of the variables used to test the hypotheses. This is followed by a description of the techniques used to analyse the data.

The function of a research design is to ensure that the evidence obtained enables us to answer the initial question as unambiguously as possible. Obtaining relevant evidence entails specifying the type of evidence needed: to answer the research question; to test a theory; to evaluate a programme; or to accurately describe some phenomenon. Or, when designing research, we need to ask: Given this research question, what type of evidence is needed to answer the question in a convincing way? Research design 'deals with a logical problem and not a logistical problem' (Yin, 1989: 29). Research design refers to the structure of an enquiry: it is a logical matter rather than a logistical one. Research design forms the framework of the research, and deals with: what questions to study; what data is relevant; what data to collect; and how to analyse the results (Marezyk et al., 2005).

\subsection{Introduction}

In previous studies (see Sahin et al., 2011a,b) a thorough investigation using the GALAXY model, inter alia, based on multivariate regression analysis and Data Envelopment Analysis (DEA), was made. In the present paper we provide a comprehensive explanatory framework for analysing the performance of ethnic entrepreneurs. Before estimating and discussing this comprehensive model, we first run several ordinal logistic models for each of the entrepreneurial Business Performance indicators. We then compare the quantitative results of both of these methods in the present GALAXY model.

The GALAXY model indicates that several selected factors (e.g. Motivational Factors (MTF), Socio-economic Contextual Factors (SEF), Business Environment (BEF), and Public Policy Factors (PPF) affect and contribute to entrepreneurial Business Performance (BPF). First, we study the separate Business Performance indicators turnover, profitability, and assets -and in our comprehensive explanatory framework we construct one Business Performance indicator based on these three elements. After presenting the theoretical background and describing the proposed research model of the entrepreneurial process in the GALAXY model, finally, in accordance with the previous review of the literature, the following main hypothesis will be tested;

"Policy Factors (PPF), Motivational Factors (MTF), Business Environment Factors (BEF), and Socip-economic Factors (SEF) have a significant influence on Business Performance (BPF)".

HO: There is no significant relationship between PPF,MTF, BEF,SEF and BPF.

$\mathrm{H} 1$ : There is a significant relationship between PPF. MTF, BEF,SEF and BPF.

This main hypothesis can subsequently be broken down into a set of sub-hypotheses, which test the individual relationships between the factors and Business Performance. The first sub-hypotheses concern the Motivational Factors. From the earlier literature review, three motivational sources were identified as: push 
factors (MTFI), availability of social networks (MTF2), and pull factors (MTF3). We suspect different entrepreneurial motivations will have a different effect on Business Performance,:

H2a: Motivational push factors (MTFI)have a negative influence on Business Performance (BPF).

H2b: Social networks (MTF2) have a positive influence on Business Performance (BPF).

H2c: Motivational pull factors (MTF3) have a positive influence on Business Performance (BPF).

The two Socio-economic Contextual Factors, relating to operational characteristics concerning the use of the Internet (SEFI) and new market access through innovation (SEF2), are both hypothesized to have a significant positive relationship on Business Performance:

H3a: Operational characteristics concerning Internet use (SEFI)have a positive influence on Business Performance (BPF).

H3b: New market access through innovation (SEF2) has a positive influence on Business Performance (BPF).

Public Policy Factors relate primarily to the level of information gathered concerning the different policy aspects of entrepreneurship and the source of this information. The hypothesis about this relationship is as follows:

H4: Public Policy Factors (PPF) have a positive influence on Business Performance (BPF).

Finally, the Business Environment factor (BEF) is primarily concerned about the location of the enterprise: both the current location (BEFI) and the start-up location (BEF2) are expected to relate to Business Performance, with businesses operating from home thought to be less efficient.

HSa: A current location at a facility away from the home (BEFI)has a positive influence on business performance (BPF)

HSb: A start-up location at a facility away from the home (BEF2) has a positive influence on business performance (BPF)

Our study used the above-mentioned factors to relate them to overall Business Performance. We investigated how entrepreneurs perform, and whether they have an increase in turnover, profitability, and assets.

\subsection{Research design and approach}

Our study analyses the main factors that have an impact on the economic performance of second-generation migrant entrepreneurs in the high-tech sector in four large cities in the Netherlands: Amsterdam, Rotterdam, Utrecht, and The Hague. In our study second- or next-generation migrants refer to those individuals born in the Netherlands with at least one parent of foreign origin. The sample in our study consists of a total of 212 entrepreneurs, who are predominantly of Turkish origin, and also few of Moroccan, Surinamese, and Antillean origin, who are active in the high-tech sector (e.g. ICT), and non-traditional sectors (e.g. FIRE (Finance, Insurance and Real Estate) and tourism services) that all require highly-educated and skilled labour.

The contributions of immigrants to job creation have not remained limited to ethnic niches and markets, but they have enlarged their market orientation to new sectors other than traditional ones and have become more 
active in the creative industries. In this study, we focus on the high-tech sector related to the advanced producer services, and knowledge-intensive business services (KIBS). Selected categories of advanced producer services are Finance, Insurance and Real Estate (FIRE), and business related professional services. Business services have been defined as "knowledge- and information intensive", and have been recognized as providers of strategic inputs to the rest of the system (Antonelli, 1998; Guerrieri and Meliciani, 2005). KIBS form a category of service activities which is often highly innovative in its own right, as well as facilitating innovation in other economic sectors, including both the industrial and manufacturing sectors. KIBS industries were defined as: (a) private companies or organizations; (b) relying heavily on professional knowledge (i.e. knowledge or expertise related to a specific technological discipline or technical functional domain); and (c) supplying intermediate products and services that are knowledge based. According to Den Hertog (2000), KIBS actually cover a rather wide range of services: namely, those KIBS that derive their intermediate function primarily from the production and transfer of technologyrelated knowledge, including, among others, engineering services and IT service firms.

The empirical data of our research was gathered from a self-administered online survey conducted in 2010 and 2011. The response rate was rather low: only 10 per cent of the targeted entrepreneurs provided complete answers to our questionnaire. A more detailed presentation of the ethnic composition of our sample and its distribution in the four biggest Dutch cities is beyond the scope of this article, but is included in another more descriptive study (see Sahin et al., 2012). This publication also contains a comparison of the selected groups. In order to determine the appropriate sample size we had to make a number of decisions: for instance, how representative the sample size would be and what methods would be used for the data analysis. This data uses Ordinal Logistic Regression, Factor Analysis, and Structural Equation Modeling (SEM), and therefore the sample choice is largely dependent on multivariate analysis requirements. One of the central requirements of this study was to have a sample size higher than 100 (Hair et al.,1998). However, Kline (2010) asserts that a 'typical' sample size in studies where SEM is used is about 200 cases, a number which corresponds to the approximate median sample size in surveys of published articles in which SEM results are presented. Therefore, a final sample size of 212 entrepreneurs was used in this study.

Our strategy for the design of the survey questionnaire was to keep it focused and short, aiming for completion within 5 to 10 minutes. To help maximize response rates, we attended network events, and asked two student-assistants to approach entrepreneurs and help them to complete the questionnaires. The questionnaire was designed in accordance with the GALAXY model, a theoretical model that takes into consideration the multiple factors that are presumed to affect the Business Performance of migrant entrepreneurs. Therefore, in order to empirically test this model we connected the questions in the questionnaire to the factors in the model. When constructing the questionnaire, we wanted to capture all the dimensions of our GALAXY model in order to be able, at a later stage, to determine the level of influence of each factor on the Business Performance of migrant entrepreneurs. The questionnaire has three parts. The first part covers the general information about the enterprise, including information about age, gender, ethnicity, and education of the entrepreneur, as well as the sector and type of the organization, etc. The second part comprises questions relating to the main factors in the GALAXY model: Motivational Factors, Business Environment, Socio-economic Contextual Factors and Policy Factors. The final part comprises questions that would help us assess the Business Performance of the enterprises. The questionnaire was initially written in English. Afterwards, as suggested by Saunders et al. (2006), a pilot study of the questionnaire was carried out on a sample of 20 people, among which were entrepreneurs of different nationalities and our fellow colleagues. It helped us determine whether all the questions were interpreted properly by the respondent, and it also helped test the reliability and validity of each question in capturing the desired information. Therefore, the feedback from the test helped us make final adjustments to the questionnaire before sending it out to the targeted groups. We removed a few questions that were not relevant for our study, especially some of the open-ended questions, as recommended by the test respondents. Furthermore, the pilot study helped 
us determine the time required to complete the questionnaire. When all the improvements had been made, the questionnaire was translated from English to Dutch.

The primary goal of this study is to assess the impact of several fundamental factors on the economic performance of second-generation migrant entrepreneurs. Our GALAXY model was constructed accordingly, with all the main factors included in the model, i.e. the Motivational Factor, the Socio-economic Contextual Factor, the Business Environment Factor, and the Policy Factor. These serve as independent input factors for the overall Business Performance of the migrant entrepreneurs. Therefore, after we had collected all the responses from our online survey, we next selected, from the full range of questions, those which could be interpreted as indicators for the input factors mentioned above. In addition, a few questions served as indicators for our output factorBusiness Performance. Table 1 gives an overview of the survey items that were selected and their relationship to the theoretical GALAXY model.

Tab1e 1Survey questions, measurement level, and link with GALAXY factors

\begin{tabular}{|c|c|c|}
\hline Factors & Survey questions & Measurement level \\
\hline \multirow[t]{6}{*}{ MTFI Push factors (bounded rationality) } & MFI.No recognition of diploma & Ordinal (1to 5) \\
\hline & MF1.2 Poverty & Ordinal (1to 5) \\
\hline & MF1.3 Unemployment & Ordinal (1to 5) \\
\hline & MF1.4 Family business continuation & Ordinal (1to 5) \\
\hline & MF1.5 Discrimination & Ordinal (1to 5) \\
\hline & MFI.G Following the role model & Ordinal (1to 5) \\
\hline \multirow[t]{6}{*}{ MTF2 Social networks } & MF2.1Employees from own ethnic group in 2009 & Ordinal (0 to 3$)$ \\
\hline & MF2.2 Employees from own ethnic group in 2010 & Ordinal (0 to 3$)$ \\
\hline & MF2.3 Employees from different groups in 2009 & Ordinal (0 to 3) \\
\hline & MF2.4 Employees from different groups in 2010 & Ordinal (0 to 3$)$ \\
\hline & MF2.5 Family members as employees in 2009 & Ordinal (0 to 3 ) \\
\hline & MF2.6 Family members as employees in 2010 & Ordinal (0 to 3) \\
\hline \multirow[t]{4}{*}{ MTF3 Pull factors (animal spirit) } & MF3.1Challenge & Ordinal (1to 5) \\
\hline & MF3.2 Motivating others & Ordinal (1to 5) \\
\hline & MF3.3 Better position & Ordinal (1to 5) \\
\hline & MF3.4 Realizing idea & Ordinal (1to 5) \\
\hline \multirow[t]{5}{*}{ SEFDperational characteristics } & SFI.Transactions with customers & Dichotomous (yes/no) \\
\hline & SF1.2 Transactions with suppliers & Dichotomous (yes/no) \\
\hline & SF1.3 Contact with suppliers & Dichotomous (yes/no) \\
\hline & SF1.4 Contact with customers & Dichotomous (yes/no) \\
\hline & SF1.5 Electronic taxation & Dichotomous (yes/no) \\
\hline \multirow[t]{5}{*}{ SEF2 Access to new markets } & SF2.1New customer service & Dichotomous (yes/no) \\
\hline & SF2.2 Training for employees & Dichotomous (yes/no) \\
\hline & SF2.3 New product process in 2009 & Dichotomous (yes/no) \\
\hline & SF2.4 New services & Dichotomous (yes/no) \\
\hline & SF2.5 New market & Dichotomous (yes/no) \\
\hline \multirow[t]{4}{*}{ PPF Public policy factors } & PFI.Advice of friends & Dichotomous (yes/no) \\
\hline & PF1.2 Advice of network organization & Dichotomous (yes/no) \\
\hline & PF1.3 Advice of customers & Dichotomous (yes/no) \\
\hline & PF1.4 Advice of consultant & Dichotomous (yes/no) \\
\hline BEFC urrent location & BEC urrent location of enterprise & Categorical \\
\hline BEF2 Start-up location & BE2 Start-up location of enterprise & Categorical \\
\hline \multirow[t]{3}{*}{ BPF Business Performance } & BPI.Profitability & Ordinal (1to 5) \\
\hline & BP1.2 Revenue & Ordinal (1to 5) \\
\hline & BP1.3 Assets & Ordinal (1to 5) \\
\hline
\end{tabular}

The first independent variable Motivational Factor (MTF) is divided into three dimensions concerning animal spirit (MTF3), bounded rationality (MTF1), and social networks (MTF2). The latter are employed by this 
study since they are frequently investigated and cited in the specialty literature. Furthermore, these can be considered as factors that focus on the individual characteristics of the entrepreneur. The second independent variable Socio-economic Contextual Factor (SEF) is constructed from dimensions referring to the access to new markets (SEF2) and the operational characteristics (SEFI\}, and therefore here we have investigated the indicators at the enterprise level. The value of the third independent variable Business Environment (BEF) was assessed by looking at its main components i.e. the start-up and current locational conditions (BEF1 and BEF2). We have chosen these two components since they can project the micro-environment in which the entrepreneurs are active. We have also used the independent input variable Policy Factor for the information gathering concerning entrepreneurial policies (PPF). We consider this fourth and last input factor to have a crucial role in the whole entrepreneurial process, but predominantly in its early phase.

From Table 1it can be clear that some dimensions had more than one indicator, and thus we had to cluster them and then recompute them into a single factor. This was done in the early stages of our research by performing both an explanatory factor analysis and a reliability check in order to investigate both the undimensionality and the reliability of the constructs for further analysis. This analysis, and the subsequent structural equation modeling will be discussed next.

\section{Study Methods and Empirical results}

\subsection{0rdinal Logistic regression}

As stated before, we first study the three different elements of entrepreneurial Business Performance separately. We estimate three different models for, respectively, assets, turnover and profitability. The dependent variable is the ordinal response to each of these three questions in the survey, i.e. respondents indicate whether their profitability 'strongly decreased', 'decreased', 'remained the same', 'increased', or 'strongly increased'. In order to explain the dependent variable we use explanatory, predictor, variables mainly including a selection of the motivational, socio-economic, business environment and policy factors mentioned in the theoretical GALAXY framework and the hypotheses, as stated in the Introduction of this chapter. Because of the clearly ordered nature of the responses in the data, the most appropriate method to use is what is called the ordered logistic regression model (for further econometric details and considerations, see, e.g., Train, 2003). Below we discuss our ordered logistic regression models for assets, turnover and profitability. Each of the three models follows the main structure of:

$$
\operatorname{Prob}(\text { Turnover outcome })=\beta_{0}+\beta_{1} M T F_{1}+\beta_{2} M T F_{2}+\beta_{3} M T F_{3}+\beta_{4} S E F_{1}+\beta_{5} S E F_{2}+\beta_{6} P P F+\beta_{7} B E F_{1}+\beta_{8} B E F_{2}+\varepsilon .(1)
$$

For each of the models, we assume that the error terms follow a logistic distribution, and therefore we estimate ordinal logit models. So, the probability of observing a certain response (e.g. 'strongly increased') to one of the business indicators depends on all explanatory variables and the error term. Furthermore, each of the explanatory factors mentioned in equation $\mathbf{1}$ can be disentangled into the separate questions asked during the survey. While the interpretation of the coefficients in these kind of models is ambiguous due to the nature of the specified logistic distribution, the signs of the coefficients and their relative values give important insights into the effects of the classified factors on entrepreneurial Business Performance. The sign of a coefficient indicates the effect of the specific level (i.e. 'strongly disagree') of that factor (i.e. poverty) relative to the effect of the reference category (i.e. 'strongly agree'). Setting the effect of the reference category equal to zero, a negative (positive) coefficient of a certain factor level (i.e. 'strongly disagree') indicates that the probability of being in a "higher" cumulative outcome category (i.e. 'strongly increased') is lower (higher) compared with someone answering the reference 
level. In general, it is the case that a greater coefficient indicates a greater probability of being in one of the "higher" cumulative outcome categories.

Assets

Table 2 shows the estimation results of the significant explanatory variables when estimating equation 1 for assets (the full estimation results are available on request). Regarding our eight hypotheses, we conclude that certain elements of the Motivational Factors (push and pull factors and social networks), socio-economic factors (access to new markets) and Public Policy Factors have a significant effect on assets at the 5 per cent significance level. Therefore, we then conclude that we cannot find supportive evidence for Hypotheses HSa and HSb (Business Environment Factors) with respect to assets.

According to Hypothesis $\mathrm{H} 2 \mathrm{a}$, we expect a negative influence of motivational push factors (MTFI) on Business Performance. Our results show that the third and fourth indicators of the motivational push factor (unemployment and family business continuation) are the only elements which have a significant effect. If the respondent indicates that 'job loss' is not the reason to start a business, a positive growth in assets is more likely than if the respondent started up the business for the reason of unemployment. The response towards the 'family business continuation' question shows a similar pattern. In particular the 'disagree' and 'neutral' levels show a positive and significant effect. Hence, these model results support our Hypothesis $\mathrm{H} 2 \mathrm{a}$. The effect of employees from different groups and different ethnic groups is related to Hypothesis H2b. The results here show that ethnicity seems to play an important role: employing more people of the same ethnicity results in an increase in assets. Furthermore, assets also increase with the total number of employees who have a different ethnic background. So, we find support for the hypothesized positive effect of social networks on Business Performance. Finally, it turns out that 'motivating others' as a reason for entrepreneurship has a positive influence on total assets, thereby indicating confirmation of Hypothesis $\mathrm{H} 2 \mathrm{c}$.

The socio-economic factors that have a significant effect on the assets level are 'training for employees', 'new product process 2009' and 'new market'. All these three elements have a positive effect on total assets, and therefore we find supporting evidence for Hypothesis $\mathrm{H} 3 \mathrm{~b}$ (concerning innovation). This is in contrast to Hypothesis $\mathrm{H} 3 \mathrm{a}$ (concerning Internet use), for which we do not find any evidence. Most surprisingly, the results in Table 2 show that the Public Policy Factor 'advice of a consultant' has a negative impact on assets. So, the only evidence we find for an effect of Public Policy Factors on assets is negative, therefore Hypothesis $\mathrm{H} 4 \mathrm{cannot}$ be supported based on these results.

Table 2 Estimation results for Assets

\begin{tabular}{|c|c|c|c|c|}
\hline \multicolumn{5}{|c|}{ ASSETS } \\
\hline Variable & level & Estimate & Std.Error & Sig. \\
\hline \multirow{5}{*}{ constant } & strongly decreased & -7.296 & 2.583 & .005 \\
\hline & decreased & -5.979 & 2.573 & .020 \\
\hline & equal & -2.330 & 2.555 & .362 \\
\hline & increased & .163 & 2.537 & .949 \\
\hline & strongly increased & $\mathrm{O}^{\prime}$ & & \\
\hline \multirow{5}{*}{ continue family business } & strongly disagree & 1.335 & .886 & .132 \\
\hline & slightly disagree & 2.056 & 1.035 & .047 \\
\hline & neither disagree or agree & 2.606 & .982 & .008 \\
\hline & slightly agree & -1.789 & 1.746 & .306 \\
\hline & strongly agree & $0^{\bullet}$ & & \\
\hline \multirow{5}{*}{ unemployment } & strongly disagree & 1.532 & .888 & .084 \\
\hline & slightly disagree & 2.274 & 1.183 & .054 \\
\hline & neither disagree or agree & .645 & .958 & .500 \\
\hline & slightly agree & -.002 & 1.044 & .998 \\
\hline & strongly agree & $0^{\circ}$ & & \\
\hline
\end{tabular}




\begin{tabular}{|c|c|c|c|c|}
\hline \multirow{4}{*}{ employees from own ethnic group in 2010} & 0 & -2.151 & 2.176 & .323 \\
\hline & $1-5$ & -4.574 & 1.909 & .017 \\
\hline & $6-10$ & -2.879 & 1.576 & .068 \\
\hline & $>10$ & $0^{\prime}$ & & \\
\hline \multirow{4}{*}{ employees from different groups in 2010} & $O$ & -7.874 & 2.199 & .000 \\
\hline & $1-5$ & -6.706 & 2.154 & .002 \\
\hline & $6-10$ & -2.970 & 1.913 & .121 \\
\hline & $>10$ & $0^{\prime}$ & & \\
\hline \multirow{4}{*}{ employees from different group in 2009} & 0 & 7.450 & 2.136 & .000 \\
\hline & $1-5$ & 6.220 & 2.007 & .002 \\
\hline & $6-10$ & 5.998 & 1.870 & .001 \\
\hline & $>10$ & $0^{\prime}$ & & \\
\hline \multirow{5}{*}{ motivate others } & strongly disagree & -1.481 & .720 & .040 \\
\hline & slightly disagree & -1.821 & .777 & .019 \\
\hline & neither disagree or agree & -.613 & .595 & .303 \\
\hline & slightly agree & -1.488 & .629 & .018 \\
\hline & strongly agree & $0^{\prime}$ & & \\
\hline \multirow{2}{*}{ training for employees } & No & .728 & .442 & .099 \\
\hline & Yes & $\mathrm{O}^{\prime}$ & & \\
\hline \multirow{2}{*}{ new production process on the market in 2009} & No & -2.599 & 1.023 & .011 \\
\hline & Yes & $0^{\prime}$ & & \\
\hline \multirow{2}{*}{ new service on the market in 2009} & No & .046 & .509 & .927 \\
\hline & Yes & $0^{\prime}$ & & \\
\hline \multirow{2}{*}{ entered a new market in 2009} & No & -1.085 & .529 & .040 \\
\hline & Yes & $\mathrm{O}^{\prime}$ & & \\
\hline \multirow{2}{*}{ advice of consultant } & No & .983 & .491 & .045 \\
\hline & Yes & $0^{\prime}$ & & \\
\hline
\end{tabular}

Note: a.Th1s parameter is set to zero because 1t Isredundant.

\section{Turnover}

Table 3 shows the estimation results of the significant explanatory variables when estimating equation $\mathbf{1}$ for turnover. Elements of the Motivational Factors (push factors and social networks), socio-economic factors (access to new markets), public policy factors, and Business Environment Factors (current and start-up location) have a significant effect on turnover at the 5 per cent significance level. Therefore, we can then conclude that we cannot find supportive evidence for the Hypotheses $\mathrm{H} 2 \mathrm{C}$ and $\mathrm{H} 3 \mathrm{a}$ with respect to turnover.

Regarding Hypothesis $\mathrm{H} 2 \mathrm{a}$, the push factors, we conclude from Table 3 that 'poverty' and 'role model' influence turnover. If the respondent indicates that poverty is the reason to start the business, his turnover will be lower compared with the case where the respondent does not mention poverty as a reason for starting the business, thereby confirming the Hypothesis for this particular element. In contrast, the results show that, if the respondents follow a 'role model', the probability of a higher turnover increases, thereby contradicting our hypothesis. According to our results, the effects of the number of employees of different backgrounds show that employing more people of different backgrounds results in a higher turnover. Therefore, we find s.upporting evidence for Hypothesis $\mathrm{H} 2 \mathrm{c}$.

The factors related to access to new markets show counterintuitive results: the factor 'training for employees' has a negative influence on turnover. Thus, entrepreneurs who provide no training opportunities for their employees have consequently increased their turnover. This contradicts Hypothesis H3b. However, 'new services' is strongly correlated with an increase in turnover, so this supports our Hypothesis.

Of all the Public Policy Factors (Hypothesis H4), only 'advice from a network' and 'advice from a consultant' show significant effects on turnover. Advice from a network has a positive effect on turnover, whereas advice from a consultant shows a negative effect. So, the evidence for this Hypothesis regarding turnover is mixed. 
Hypotheses Sa and Sb state that current and start-up locations have a positive influence on Business Performance. Because the home location has a stronger influence on turnover than the enterprise building, with the entrepreneurs' own office having the strongest influence, we do not find supportive evidence for Hypothesis Sa. Concerning the start-up location we find that all the locations have almost the same order of magnitude in their effect to turnover, so these results do not support Hypothesis Sb.

Table 3 Estimation results for Turnover

\begin{tabular}{|c|c|c|c|c|}
\hline \multicolumn{5}{|c|}{ TURNOVER } \\
\hline $\begin{array}{l}\text { Variable } \\
\end{array}$ & Level & Estimate & Std.Error & Sig. \\
\hline \multirow{5}{*}{ constant } & strongly decreased & -6.342 & 2.360 & .007 \\
\hline & decreased & -4.843 & 2.349 & .039 \\
\hline & equal & -2.973 & 2.340 & .204 \\
\hline & increased & -.484 & 2.322 & .835 \\
\hline & strongly increased & $0^{\bullet}$ & & \\
\hline \multirow{5}{*}{ poverty } & strongly disagree & -2.812 & 1.299 & .022 \\
\hline & slightly disagree & -2.342 & 1.510 & .121 \\
\hline & neither disagree or agree & -1.292 & 1.327 & .330 \\
\hline & slightly agree & -4.755 & 1.886 & .012 \\
\hline & strongly agree & $0^{\bullet}$ & & \\
\hline \multirow{5}{*}{ follow role model } & strongly disagree & 1.357 & .745 & .069 \\
\hline & slightly disagree & 1.528 & .923 & 3.337 \\
\hline & neither disagree or agree & 1.615 & .838 & 3.258 \\
\hline & slightly agree & 2.640 & .985 & 4.571 \\
\hline & strongly agree & $0^{\bullet}$ & & \\
\hline \multirow{4}{*}{ employees from different group in 2010} & 0 & -5.396 & 1.935 & .005 \\
\hline & $1-5$ & -4.632 & 1.887 & .014 \\
\hline & $6-10$ & -3.306 & 1.765 & .061 \\
\hline & $>10$ & $0^{\circ}$ & & \\
\hline \multirow{4}{*}{ employees from different groups in 2009} & 0 & 4.009 & 1.867 & .032 \\
\hline & $1-5$ & 3.607 & 1.751 & .039 \\
\hline & $6-10$ & 4.152 & 1.697 & .014 \\
\hline & $>10$ & & & \\
\hline \multirow{2}{*}{ training for employees } & no & .689 & .406 & .090 \\
\hline & yes & $0^{\circ}$ & & \\
\hline \multirow{2}{*}{ new services on the market } & no & -.917 & .476 & .054 \\
\hline & yes & $0^{\bullet}$ & & \\
\hline \multirow{5}{*}{ current location } & home & 3.554 & 1.154 & .002 \\
\hline & incubator & $0^{\circ}$ & & \\
\hline & enterprise building & 2.726 & 1.127 & .016 \\
\hline & own office & 3.690 & 1.135 & .001 \\
\hline & other & $0^{\bullet}$ & & \\
\hline \multirow{5}{*}{ Start-up location } & home & -2.079 & 1.232 & .091 \\
\hline & incubator & -2.683 & 1.594 & .092 \\
\hline & enterprise building & -2.015 & 1.252 & .107 \\
\hline & own office & -2.176 & 1.279 & .089 \\
\hline & other & $0^{\bullet}$ & & \\
\hline \multirow{2}{*}{ advice of network organization } & no & -.927 & .383 & .016 \\
\hline & yes & $0^{\bullet}$ & & \\
\hline \multirow{2}{*}{ advice of consultant } & no & 1.249 & .451 & .006 \\
\hline & yes & $0^{\bullet}$ & & \\
\hline
\end{tabular}

Note: a. This parameter is set to zero because it is redundant.

\section{Profitability}

Table 4 shows the estimation results of the significant explanatory variables when estimating equation $\mathbf{1}$ for profitability. Elements of the Motivational Factors (push factors and social networks), Public Policy Factors, and Business Environment Factors (current and start-up location) have a significant effect on profitability at the $S$ per 
cent significance level. Therefore, we can then conclude that we cannot find supportive evidence for Hypotheses $\mathrm{H} 2 \mathrm{C}, \mathrm{H} 3 \mathrm{a}$, and $\mathrm{H} 3 \mathrm{~b}$ with respect to profitability.

Concerning Hypothesis $\mathrm{H} 2 \mathrm{a}$ we do find the same qualitative results for profitability as for turnover in the last section. So, indicating poverty as a reason for entrepreneurship and following a role model as a reason have, respectively, a negative and positive effect on profitability. Therefore, the evidence for Hypothesis $\mathrm{H} 2 \mathrm{a}$ is mixed. From the social network factors, Hypothesis $\mathrm{H} 2 \mathrm{~b}$, only ethnicity plays a role: employing more people of the same ethnicity results in a higher profitability.

The effects of public policy on profitability are qualitative, the same as for turnover. Advice from a network organization has a positive effect on profits, whereas the effects of the advice of a consultant are, surprisingly, negative. So, the evidence concerning Hypothesis $\mathrm{H} 4$ is mixed.

The results for current and start-up location with respect to profitability are also largely similar to the effects found for turnover. In turns out that both 'home' and 'own office' have a large positive effect on profitability. This result does not support the Hypothesis that extramural facilities have an extra positive influence on profitability (Hypothesis HSa). The same holds for the start-up location, all the locations possible show the same order of magnitude in their effects on profitability.

Table 4 Estimation results for Profitability

\begin{tabular}{|c|c|c|c|c|}
\hline \multicolumn{5}{|c|}{ PROFITABILITY } \\
\hline Variable & Level & Estimate & Std.Error & Sig. \\
\hline \multirow{5}{*}{ constant } & strongly decreased & 6.508 & 2.388 & .006 \\
\hline & decreased & -4.883 & 2.337 & .040 \\
\hline & equal & -2.850 & 2.367 & .229 \\
\hline & increased & -.255 & 2.350 & .914 \\
\hline & strongly increased & $0^{\bullet}$ & & \\
\hline \multirow{5}{*}{ poverty } & strongly disagree & -2.355 & 1.235 & .057 \\
\hline & slightly disagree & -1.530 & 1.513 & .312 \\
\hline & neither disagree or agree & -.600 & 1.338 & .654 \\
\hline & slightly agree & -4.740 & 1.986 & .017 \\
\hline & strongly agree & $0^{\bullet}$ & & \\
\hline \multirow{5}{*}{ follow role model } & strongly disagree & .942 & .754 & .211 \\
\hline & slightly disagree & .838 & .933 & .369 \\
\hline & neither disagree or agree & 1.487 & .855 & .082 \\
\hline & slightly agree & 2.671 & 1.003 & .008 \\
\hline & strongly agree & $0^{\bullet}$ & & \\
\hline \multirow{4}{*}{ Employees from own ethnic group } & 0 & -3.458 & 2.140 & .106 \\
\hline & $1-5$ & -4.087 & 1.903 & .032 \\
\hline & $6-10$ & -2.155 & 1.606 & .180 \\
\hline & $>10$ & $0^{\bullet}$ & & \\
\hline \multirow{4}{*}{ employees from different groups } & $O$ & -5.244 & 2.073 & .011 \\
\hline & $1-5$ & -4.519 & 2.047 & .027 \\
\hline & $6-10$ & -2.951 & 1.925 & .125 \\
\hline & $>10$ & $\mathrm{O}^{\prime}$ & & \\
\hline \multirow{5}{*}{ current location } & home & 3.830 & 1.167 & .001 \\
\hline & incubator & 1.797 & $1.562 \quad-$ & .250 \\
\hline & enterprise building & 2.882 & 1.140 & .011 \\
\hline & own office & 3.864 & 1.148 & .001 \\
\hline & other & $0^{\prime}$ & & \\
\hline \multirow{5}{*}{ Start-up location } & home & -2.399 & 1.248 & .054 \\
\hline & incubator & -2.187 & 1.619 & .177 \\
\hline & enterprise building & -2.451 & 1.272 & .054 \\
\hline & own office & -2.488 & 1.295 & .055 \\
\hline & other & $0^{\bullet}$ & & \\
\hline \multirow{2}{*}{ advice of network organization } & no & -1.040 & .390 & .008 \\
\hline & yes & $\mathrm{O}^{\prime}$ & & \\
\hline advice of consultant & no & .978 & .453 & .031 \\
\hline
\end{tabular}


\begin{tabular}{|c|l|l|l|}
\hline yes & $0^{\text {a }}$ & $\cdot$ &. \\
\hline
\end{tabular}

Note: a. This parameter is set to zero because it is redundant.

The above discussion of the ordered logit models for the separate elements of Business Performance indicators and the explanatory factors (elements) shows mixed results regarding the hypotheses formulated in Section 4.1. Therefore, we continue with an integrative model in the next session.

\subsection{A structural equations model}

The proposed model and hypothesized relationships between the different variables of the GALAXY model were tested using the AMOS 19 structural equation modeling package (SEM) for SPSS. Before running the structural equation modeling software, however, some data transformations had to be performed. First of all, patterns of missing data were analysed. All in all, only a few items contained some missing data, with MF3.2, MF3.2 and BEl earh having one unrelated piece of missing data. Because of the very limited nature of the missing data, a simple sample mean imputation was performed in order to construct a full data set. A second transformation pertained to the measurement levels of the survey items. Since SEM assumes variables on the interval or ratio measurement level, nominal variables can only be incorporated when receded as a collection of dummy variables. Consequently, the business environment factor measured by the questions: 'current location' and 'starting location', was receded as a dummy variable. The original nominal scale with categories: 'home', 'incubator', 'business park', 'office premises', and 'other', was transformed into a dichotomous variable, with a code 0 for home enterprises, and $\mathbf{1}$ for entrepreneurs operating from business locations away from home. All other measurement items were measured on either the ordinal (the indicators for Motivational Factors, Public Policy Factors, and Business Performance) or the dichotomous categorical (the indicators for socio-economic variables) scale, and did not require data manipulation.

In accordance with Mulaik and Millsap's (2000) suggestions, a four-step modelling approach was used in order to test our theoretical model:

1. Explanatory factor analysis to establish the number of latent variables;

2. Confirmatory factor analysis to confirm the measurement model;

3. A structural model to test the relationships between the model variables;

4. Nested models testing in order to identify the most parsimonious model.

While Steps 2 to 4 are part of SEM software, the first step was performed in SPSS 17.0. The unidimensionality of each proposed construct of the model was assessed using Principal Component Analysis to assure that the measurement items had only one underlying construct in common (Sethi and King, 1994). Use of the polychoric and tetrachoric correlation matrix was preferred over the more common Pearson's productmoment correlation, as suggested by Joreskog and Sorbom (1996), who observed that lack of variability in ordinal data correlations can limit the lower and upper limit of Pearson's Correlation to, respectively, -0.5 and 0.5 , leading to Kubinger's (2003) notion that factor analysis on Pearon's correlation matrices will often lead to artificial factors. To obtain the polychoric correlation matrix, we used the polycor package in $\mathrm{R}$ and read this matrix into SPSS for use in subsequent analyses.

According to Ho and Li (2006), an ordinal measurement level is sufficient in order to perform explanatory factor analysis. Other necessary assumptions all concern the correlation between variables, which should be sufficient without being overly strong or perfect. The Kaiser-Meyer Olin statistic furthermore tests whether the pattern of correlations is diffused or compact, with values above 0.5 deemed acceptable. Finally, Bartlett's test of spherity tests the null hypothesis that the original correlation matrix is singular (Field,2000). 
Our initial Principal Component Analysis on the motivation factors resulted in an error message resulting from a nonpositive definite matrix. While there can be multiple reasons for encountering strictly positive eigenvalues of a matrix (for a full review, see Wothke,1993), linear dependency between variables can be one of the main problems. Careful inspection of the correlation matrix identified a potential problem between items MF2.1 and MF2.2, items MF2.3 and MF2.4 and items MF2.5 and MF2.6 with correlation coefficients of 0.994, 0.980 , and 0.994 , respectively. Since these measurement items concern the employment of ethnic employees (ethnic groups, other, and family) in 2009 and 2010, it can be assumed that the difference in employment over the course of 2 years is minimal, hence the almost perfect correlation. In the subsequent analysis, measurement items MF2.1, MF2.3, and MF2.5 (all concerning the year 2009) were eliminated and the Confirmatory Factor Analysis was run again. This time the results confirmed its general validity, with the Kaiser-Meyer-Olin (KMO) measure of sampling adequacy equal to 0.724 and Bartlett's Test of Sphericity being very significant (.000). The correlation matrix shows satisfying correlations with a determinant of 0.002 , which is bigger than the norm of 0.00001 , rejecting the hypothesis of multicollinearity.

Both the use of the eigenvalue method, meaning that only factors having eigenvalues greater than $\mathbf{1}$ are considered significant, and use of the scree plot, resulted in a solution with three components, which explain a total of 62.528 per cent of the variance.

Table 5 Varimax Rotated Component Matrix of Motivation Factors

\begin{tabular}{|l|l|l|l|}
\hline Items & Component & \\
\hline & 1 & 2 & 3 \\
\hline MF1.1No recognition of diploma & .894 & -.110 & .053 \\
\hline MF1.2 Poverty & .876 & -.045 & -.081 \\
\hline MF1.3 Unemployment & .803 & .009 & .002 \\
\hline MF1.4 Family business continuation & .772 & -.010 & -.020 \\
\hline MF1.5 Discrimination & .729 & -.121 & -.065 \\
\hline MF1.6 Following the role model & .699 & .396 & -.089 \\
\hline MF2.2 Employees from own ethnic group in 2010 & .115 & .196 & .863 \\
\hline MF2.4 Employees from different groups in 2010 & -.139 & .111 & .677 \\
\hline MF2.6 Family members as employees in 2010 & -.043 & -.165 & .700 \\
\hline MF3.1Challenge & -.306 & .787 & .101 \\
\hline MF3.2 Motivating others & .109 & .763 & .146 \\
\hline MF3.3 Better position & .167 & .626 & -.139 \\
\hline MF3.4 Realizing idea & -.429 & .561 & .110 \\
\hline Cronbach's alpha & .817 & .808 & .629 \\
\hline
\end{tabular}

Varimax rotation was used to obtain a clearer interpretation of the factors. Table 5 shows the factor loadings of the different measurement items on the respective components. The results are in line with our theoretical considerations, dividing the motivational factor into push-factors (or bounded rationality), which concern items such as poverty, unemployment, and discrimination, social networks: specifically, the employability of ethic employees, and pull-factors (or entrepreneurial animal spirit), which combine items such as looking for a challenge, realizing ideas, and creating a better position for oneself. Cronbach's alpha was calculated separately for all three factors, showing acceptable to good internal consistency. As a result, three Motivational Factors: push factors (MTF1), social networks (MTF2), and pull factors (MTF3) are incorporated in the measurement model.

A first Principal Component Analysis failed to identify underlying data dimensions, owing to a nonpositive definite correlation matrix. A sequential analysis of the correlation matrix, deleting one variable at a time and computing the determinant, identified a problem with item SF1.2, which was subsequently left out of the analysis. 
The new correlation matrix resulted in a KMO measure of sampling adequacy of 0.413 and a p-value of Bartlett's test of Sphericity of .000 . The KMO was below the threshold level, indicating that the items would potentially not factor well. A two-factor solution is given as the eigenvalues rule-of-thumb. The total variance explained by the two factors is 71.347 per cent.

Table 6 Varimax Rotated Component Matrix of Socio-economic Factors

\begin{tabular}{|l|l|l|}
\hline Items & Component \\
\hline & 1 & 2 \\
\hline SF1.1Transactions with customers & .169 & .906 \\
\hline SF1.3 Contact with suppliers & .035 & .853 \\
\hline SF1.4 Contact with customers & -.204 & .920 \\
\hline SF1.5 Electronic taxation & -.003 & .824 \\
\hline SF2.1New customer service & .800 & -.003 \\
\hline SF2.2 Training for employees & .762 & -.130 \\
\hline SF2.3 New production process in 2009 & .882 & .131 \\
\hline SF2.4 New services & .812 & -.121 \\
\hline SF2.5 New market & .740 & .149 \\
\hline Cronbach's alpha & .771 & .636 \\
\hline
\end{tabular}

Table 6 gives an overview of the construction of the two Socio-economic Contextual Factors. Factor 1 combines all the variables indicating Internet use for transactions, contacts, and electronic taxation (SEF1). The second component, Factor 2, is mainly dependent on innovations in services, and markets, and is therefore described as 'innovation' (SEF2).

The factor analysis of Public Policy Factors also indicates. general validity, with a KMO of .726, and a significant Bartlett's Test of Sphericity (.000). Multicollinearity could be rejected (determinant $=.381$ ). The eigenvalue-method proposes a one-factor solution which is also supported by a visual check of the scree plot. Table 7 shows the resulting one-factor varimax rotated solution, which explains 56.909 per cent of the total variance in the data set.

Table7 Varimax Rotated Component Matrix of Public Policy Factors

\begin{tabular}{|l|l|}
\hline Items & Component \\
\hline & 1 \\
\hline PF1.1Advice of friends & .859 \\
\hline PF1.2 Advice of network organization & .733 \\
\hline PF1.3 Advice of customers & .783 \\
\hline PF1.4 Advice of consultant & .622 \\
\hline Cronbach's alpha & .561 \\
\hline
\end{tabular}

Different from the theoretical GAIAXY model, the operationalization of the policy factor is strictly onedimensional, with the constructed component measuring the extent to which entrepreneurs have gathered advice from a range of sources concerning regulatory, institutional, and financial incentives. The Cronbach's alpha value for internal consistency shows a rather weak internal consistency of .561, with a possible increase to .986 if item PF1.4 Advice of consultant is deleted. However, at this point, we are primarily concerned with the unidimensionality in the constructs and the potential exclusion of items will be further analysed in the measurement and structural models.

Finally, Exploratory Factor Analysis was used to test the unidimensionality of the Business Performance Factor. Both the KMO (.741) and the Bartlett's Test of Sphericity (.000) accept the use of factor analysis on our 
data. The correlation coefficients are sufficiently high, but there is no reason to suspect multicollinearity with a determinant of .014. A one-factor solution explains 94.151per cent of the total variance with the varimax rotated factor loadings given in Table 8.

Table 8 Varimax Rotated Component Matrix of Business Performance

\begin{tabular}{|l|l|}
\hline Items & Component \\
\hline & 1 \\
\hline BP1.1Profitability & .983 \\
\hline BP1.2 Revenue & .976 \\
\hline BP1.3 Assets & .951 \\
\hline Cronbach's alpha & .944 \\
\hline
\end{tabular}

The Exploratory Factor Analysis results in a one-dimensional construct, combining profitability, revenue, and assets. The high Cronbach's alpha value is further proof of the acceptability of using Business Performance as a singular latent variable, with BP1.1,BP1.2, and BP1.3 as measurement items.

After conducting Exploratory Factor Analysis to identify the different latent dimensions in the data and the convergent validity of the indicators, Confirmatory Factor Analysis tests the adequacy of individual items and reliability and the divergent validity of the latent variable constructions in an overall measurement model. Before performing parameter estimation with AMOS, it is important to verify the data considerations in order to perform SEM, since deviations with respect to these requirements influence the estimation method and parameter reliability. Earlier remarks concerning the measurement level of the data in factor analysis are also applicable in SEM estimation. Since most estimation and model fit procedures are based on calculations of the variancecovariance matrix, ordinal-level measurement scales can influence the parameter estimations under Maximum Likelihood estimation. Closely related to the measurement scale is the issue of normality. SEM requires a multivariate normal distribution, implying a univariate distribution for every variable, and a bivariate normal distribution between pairs of variables (Gao et al., 2008). Nonnormality, which can, among other things, occur because of the scaling of variables or limited sampling of subjects, will affect the variance-covariance among variables (Schumacker and Lomax, 2004). While Muthen and Kaplan (1985) conclude that not much distortion in chi-square and parameter estimation is expected from using Maximum Likelihood or Generalized Least Squares estimation on non-multivariate normal data, if the univariate skewnesses and kurtoses remain within the range of -1.0 and +1.0 , but skewnesses and kurtoses above an absolute value of 2.0 are cause for greater concern.

While the measurement level of the different variables has been established before as being ordinal or dichotomous, with nominal variables recoded into a set of dummy items, the normality of the data can be tested by assessing skewness, kurtosis, Mardia's coefficient, and the squared Mahalanobis distance. A value below the critical ratio of 1.96 on Mardia's coefficient of multivariate kurtosis would imply a normal multivariate distribution. Higher values of the squared Mahalanobis distance, on the other hand, indicate larger differences between observations and the centroid under normality assumptions, and are therefore a sign of outliers influencing nonmultivariate normality (Sharma, 1996). Since Mardia's coefficient of our data set has a critical ratio of 11.170 , we have to assume a significant non-normality in the data. Furthermore, the largest squared Mahalanobis distances and associated significance values show that at least 56 observations are improbably far from the centroid to assume normality. Following the advice of Muthen and Kaplan (1985), we subsequently check the univariate skewness and kurtosis of the data. A large number of variables show skewness and kurtosis above the absolute value of 2.0, which leads us to conclude that the data distribution is not suited for estimation methods like Maximum Likelihood or Generalized Least Squares that require normality.

The approach proposed by Joreskog and Sorbom (1996) in the case of below-interval measurement level of data and a significant non-normal distribution is an Asymptotic Distribution Free estimation method based on the 
polyserial, polychoric, or tetrachoric correlation matrix. However, Yung and Bentler (1994) have indicated the need for a large sample size (at least 2,000, and preferably as high as 5,000) in order for this method to generate satisfactory results. On the other hand, AMOS offers an alternative estimation method by applying a Bayesian framework with ordinal,non-normal data. In the context of the Bayesian approach, every parameter is treated as a random variable with a probability distribution. A hypothesized prior probability distribution is combined with empirical evidence of the sample data through the use of Bayes' theorem and leads to a posterior distribution. Uncertainty in the parameter estimates is reduced by the acquisition of new data, generated from the original sample through a Markov Chain Monte Carlo algorithm (Arbuckle, 2009; Byrne, 2010).

It was decided to further use this Bayesian approach in our subsequent Confirmatory Factor Analysis and SEM as a result of the violations against distribution and measurement assumptions, combined with the limited sample size. However, since diverse authors have also observed only marginal differences between Maximum Likelihood and Bayesian estimation outcomes (Byrne, 2010), we have opted to run a simultaneous Maximum Likelihood estimation in order to compare results and model fit indices.

The measurement model was constructed based on the previously identified dimensions. Following Garson (2011), we assume correlation between the different latent exogenous variables (depicted by a double-headed arrow). Maximum Likelihood estimation gave an overall fit of the original measurement model of $X^{2}=629.691(p=$ .000), indicating a significant difference between the observed and implied variance-covariance matrices. However,Schumacker and Lomax (2004) note that the $X^{2}$ statistic is sensitive to sample size and departures from multivariate normality, with a tendency to indicate a significant probability level if the sample size increases above 200 , and the model is comparatively complex. This is also indicated by dividing the $X^{2}$ by the degrees of freedom, and using this statistic as an index. With a value of $1.543(<3)$, this $X^{2} / \mathrm{df}$ indicates a good model fit (Mindrila, 2010). Therefore, Tabachnick and Fidell (1996) mention that a non-significant chi-square value,combined with reasonable results on the other fit indices can still mean that it is feasible to continue working with the theorized model. Of the fit indices available in structural equation modeling, Fan et al. (2011) mention that the root mean square error of approximation (RMSEA) and the McDonald Centrality Index perform well under different sample size and on sensitivity to model misspecification, while the Comparative Fit Index (CFI) is less sensitive to model misspecification, but also performs well for small samples. The RMSEA was, at 0.051, slightly higher than the maximum of 0.05 that indicates a good fit. The CFI had a value of 0.893 , with values of 0.9 or higher indicating a good fit. The Normed Fit Index (NFI) was 0.752, with a Parsimonious Normed Fit Index (PNFI) of 0.660 and an Akaika Information Criterion (AIC) of 867.691. Apart from looking at the total model fit indices, the significance of the individual factor loadings should also be considered. Only two measurement items, MF2.6 and MF3.3 had nonsignificant factor loadings at the 99 per cent confidence interval, with standardized regression weights below the minimal level of 0.30 (Hair et al., 1998; Merenda, 1997). The Bayesian estimation procedure shows largely comparable parameter estimates, while the available model fit indices in the Bayesian analysis have the following values: Deviance Information Criterion $(D I C)=871.01$, a posterior predictive $p=0.00$, with values towards the extremes of 0 and 1 indicating non-plausible models (Lee and Song, 2003), and an effective number of parameters $=113.05$. Both estimation methods showed potential improvement by correlating measurement errors and fixing the regression weight of some variables to zero. However, Silvia and MacCallum (1988) warn against the use of modification indices without theoretical justification, since this might overfit the model to data noise and fluctuations in the sample data (Garson, 2011). Specifically, correlation in error terms is reserved for situations where the residual of one indicator helps in estimating the residual in another indicator. This might, for instance, be the case when similar measurement scales are used in different questions. Taking these warnings into account, we now have to provide the theoretical background to the decision to correlate the error terms.

The measurement model was respecified by including correlations between the error terms of: MF1.1(no recognition of diploma) and MF1.5 (discrimination); MF1.6 (following the role model) and MF3.3 (better position); 
and MF3.2 (motivating others) and MF3.3 (better position). All these variables were measured on a comparable scale where it can be presumed that the answers could be influenced by social acceptability. A further modification was made by eliminating the paths between the measurement items MF2.6, MF3.3 and their respective latent variables, since deleting these items also resulted in an improvement of the Cronbach's alpha for MTF2 (from 0.808 to 0.814 ) and MTF3 (from 0.629 to 0.661 ). Since no significant cross-loadings between indicators and other latent variables were indicated, no problems with convergent validity were expected, and no further modifications were made (Kline, 2010). The model fit indices generated by Maximum Likelihood estimation improved to an RMSEA of 0.047 , a CFI of .906, a NFI of 0.757, a PNFI .689, and a $X^{2} / d f$ of 1.458 . The AIC had a value of 824.793, and the $X^{2}$ was significant $(p=.000)$ at 616.793 . While the $X^{2}$-value is still significant, and both NFI and PNFI are rather low, the RMSEA and CFI show a model with a reasonably good fit, and the AIC indicates an improvement of the model. Furthermore, all individual factor loadings are significant at a 99 per cent confidence interval. The Bayesian estimation model converged with a convergence criterion of 1.0019 , a posterior predictive $\mathrm{p}$ of 0.00 , an improved DIC of 829.09 (where smaller values of DIC are preferred over larger values), and an effective number of parameters of 101 . The regression weights were all significant and comparable to the Maximum Likelihood estimates.

After confirming the reliability and validity of the latent variable constructs, the structural model was constructed, based on the theoretical GALAXY model. Figure 2 shows the constructed latent variables and the paths between the latent variables and the endogenous variable Business Performance. When comparing Figure 1 with Figure 2 some differences between the theoretical model and the structural model are obvious. First, while it might seem from the GALAXY model that Motivational Factors, Socio-economic Contextual Factors, Business Environment, and Policy Factors are all latent factors constructed from a collection of observed variables, in fact these exogenous variables from the theoretical model are themselves latent variables. This was already identified in the earlier Exploratory Factor Analysis. Second, not all variables from the theoretical model were measured by the survey, therefore 'Policy Factors' is represented by a single variable, as is 'Business Environment' which is coded as a set of dummy variables for current and start-up locations. Finally, the Socio-economic Contextual Factor consists of two dimensions in our structural equation model, instead of the theorized three dimensions.

In a first step, the complete regression model was tested (both full and dashed arrows in Figure 2) on path significance. It should be noted that, in line with the earlier conclusions from the measurement models, the paths between MTF2 and MF2.6 and between MTF3 and MF3.3 were set to zero. Furthermore, since both DBE1and DBE2 are dummy-coded variables, their error terms (627 and 628) were given a mean and variance of zero. Lastly, while not shown in Figure 2 for reasons of simplicity, there are significant covariances between the latent variables (MTF1<-> MTF3, MTF3 <-> SEF2, MTF2 <-> SEF2, SEFI<-> PPF, BEF2 <-> BEF1, MTF2 <-> BEF1, BEF2 <-> MTF2, MTF3 <-> SEF1, SEF2 <-> BEF1, and SEF3<-> PPF) and between the error terms (66<-> 612, $65<->61$, and $612<->$ 611).

The result of the initial Maximum Likelihood estimation procedure revealed a non-significant chi-square value $\left(X^{2}=599.906, p=.000\right)$, with model fit indices of RMSEA $=0.046, \mathrm{CFI}=.911, \mathrm{NFI}=0.764, \mathrm{PNFI}=.681, \quad \mathrm{X}^{2} / \mathrm{df}$ $=1.446$, and $\mathrm{AIC}=823.906$, indicating a potential for model improvement. Furthermore, none of the hypothesized relationships between the latent variables and Business Performance was found to be significant at a 95 per cent confidence level. The same results were generated with Bayesian estimation, which failed to converge with a convergence criterion of 1.0256 , therefore resulting in unstable parameter estimates. None of the weights for the regression paths were significantly different from zero. 


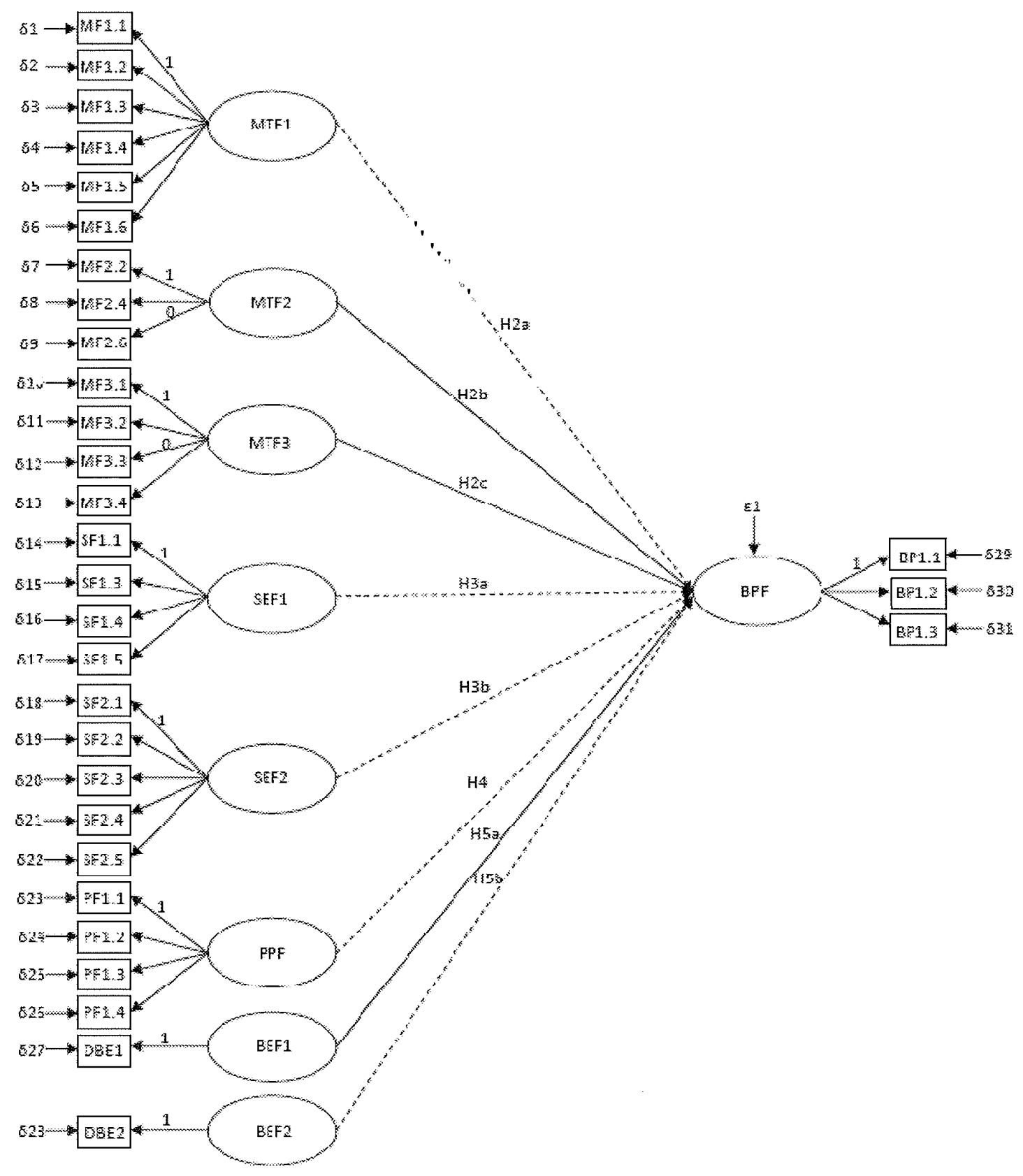

Note: Dashed lines were included in the first structural model and excluded in the second model.

Figure 2 Final Structural Equation Model

Next, a series of nested structural models were tested through the AMOS specification search in order to identify the best fitting model for the data. A total of 68 different models were tested on top of the saturated model. Table 9 gives an overview of the significance tests between the original model, eight models with every regression tested individually, and the best fitting model with five paths fixed to zero. 
Table 9 Significance test of nested models

\begin{tabular}{|l|l|l|l|l|l|l|}
\hline Model & Description & $\mathrm{df}$ & $\mathrm{XZ}$ & $\mathrm{X}^{2} / \mathrm{df}$ & $\mathrm{BCCO}$ & $\mathrm{D}^{2}\left(=\mathrm{X}^{2}\right.$ orillinal- $\mathrm{X}^{2}$ ail \\
\hline $\mathbf{1}$ & Original (full) model & 415 & 599.906 & 1.446 & 11.009 & \\
\hline 2 & Only path between SEF2 and BPF & 422 & 607.995 & 1.441 & 2.595 & 8.089 \\
\hline 3 & Only path between MTF3 and BPF & 422 & 608.367 & 1.442 & 2.967 & 8.461 \\
\hline 4 & Only path between MTF1and BPF & 422 & 613.696 & 1.454 & 8.296 & 13.790 \\
\hline 5 & Only path between MTF2 and BPF & 422 & 614.385 & 1.456 & 8.985 & 14.479 \\
\hline 6 & Only path between SEFl and BPF & 422 & 614.660 & 1.457 & 9.260 & 14.754 \\
\hline 7 & Only path between BEF1and BPF & 422 & 616.161 & 1.460 & 10.761 & 16.255 \\
\hline 8 & Only path between BEF2 and BPF & 422 & 616.622 & 1.461 & 11.222 & 16.716 \\
\hline 9 & Only path between PPF and BPF & 422 & 616.791 & 1.462 & 11.391 & 16.885 \\
\hline 10 & Path between MTF2,MTF3, BEF1and BPF & 420 & 562.044 & 1.348 & 0.000 & 37.862 \\
\hline
\end{tabular}

Apart from looking at the model fit values, a Likelihood ratio test was performed where the difference $D^{2}$ between the $X^{2}$-values of the full model and the nested models was compared with that between the tabled $X^{2}$ values for the related degrees of freedom (= Idfariginal- $d f . I)$. In general, a lower $X^{2}$-value is preferred over a higher value, while for an insignificant $X^{2}$ difference between the full and the constrained model, the modification should be accepted on grounds of parsimony (Garson, 2011). From Table 9 we can see that Models 2 to 9 have a higher $X^{2}$ value. The question then is to investigate whether this higher value is significantly different. The tabled $X^{2}$-value for 7 degrees of freedom and an a-level of 0.05 is 14.067. Comparing these tabled values with the $D^{2}$ values of Table 9 , we can reject Models 5 to 9 , while Models 2,3, and 4 do not show a significant difference in $x^{2}$-value with the original model and should therefore be preferred on grounds of parsimony. However, Model 10 shows a preferable lower $X^{2}$-value of 562.044 as compared to both the original and one-path models. The $X^{2}$-value for 5 degrees of freedom and a 0.05 a-level is 11.070 . Therefore, the $D^{2}$-value is significant and positive, making this the most preferred model. This analysis can be further extended since Models 2 to 9 are themselves nested models of Model 10. Performing a new Likelihood ratio test with Model 10 as the original model, we find a significant difference for all $X^{2}$-values with $D^{2}$-values of $37.862,45.951,46.323,51.652,52.341,52.616,54.117$, and 54.578 compared with a tabled $X^{2}$-value of 5.991 , meaning we cannot reject Model 10 in favour of the more parsimonious Models 2 to 9 .

In the final Model 10, five paths were fixed at zero with only an expected regression between MTF2,MTF3, $\mathrm{BEFI}$ and the dependant variable BPF. The overall model fit statistics of Maximum Likelihood Estimation indicate that the accepted model fits the data better than the original model, with an improvement in RMSEA (.041), CFI (.930), PNFI (.834), $X^{2} / d f$ \{1.348), AIC \{782.044), and NFI 0.778$)$. The $X^{2}$-value of 562.044 , however, still remains non-significant $(p=.000)$. While we discussed before that the significance of the $X^{2}$-value is dependent on normality and sample size, the non-significance is troublesome since a number of authors argue that the $X^{2}$-test is the only substantive test of fit for SEM (Barrett, 2007). Thankfully, AMOS offers an alternative $X^{2}$ fit test for nonnormal data by using the Bollen-Stine Bootstrap. Running the test with 2000 bootstrap samples, we get a p-value of .057 . As a result we can accept the null hypothesis that our model is correct. Different from the original SEM, the regression weights between MTF2, MTF3, BEFI and BPF are now significant at a 95 per cent confidence interval, with MTFI and MTF3 having a positive influence, while the influence of BEF1on BPF shows a negative sign. The same conclusions can be drawn from the Bayesian analysis, with significant positive weights for MTF2 and MTF3, and a negative value for the regression weight of BEFI. Moreover, the Bayesian estimation procedure did converge this time, with a convergence criterion of 1.0020 , a posterior predicitive $p$ which is still unsatisfactory at 0.00 , a DIC of 817.68 , and an effective number of parameters of 103.41 . The factor loadings and regression weights of both the Maximum Likelihood and the Bayesian estimation are compared in Table 10. 
Table 10 Unstandardized parameter estimates with Maximum Likelihood and Bayesian Estimation: final structural equation model

\begin{tabular}{|c|c|c|c|c|c|c|c|}
\hline & \multicolumn{3}{|c|}{ Maximum Likelihood } & \multicolumn{4}{|c|}{ Bayesian Estimation } \\
\hline & Estimate & SE & $\mathrm{P}$-value & Estimate & SE & 95\% Lower bound & 95\% Upper bound \\
\hline MF1.2<-MTF1 & .920 & .078 & $<.001$ & .944 & .004 & .790 & 1.123 \\
\hline MF1.3<-MTF1 & .718 & .088 & $<.001$ & .732 & .003 & .550 & .926 \\
\hline MF1.4<-MTF1 & .776 & .090 & $<.001$ & .793 & .004 & .610 & .994 \\
\hline MF1.5<-MTF1 & .775 & .087 & $<.001$ & .780 & .003 & .606 & .960 \\
\hline MF1.6<-MTF1 & .636 & .091 & $<.001$ & .644 & .004 & .462 & .848 \\
\hline MF2.4<-MTF2 & 0.926 & .161 & $<.001$ & 1.110 & .007 & .775 & 1.520 \\
\hline MF2.6<-MTF2 & 0.000 & & & 0.000 & & & \\
\hline MF3.2<-MTF3 & .539 & .098 & $<.001$ & .520 & .003 & .344 & .720 \\
\hline MF3.3<-MTF3 & 0.000 & & & 0.000 & & & \\
\hline MF3.4<-MTF3 & .681 & .112 & $<.001$ & .611 & .005 & .385 & .877 \\
\hline SF1.3<-SEF1 & .900 & .099 & $<.001$ & .903 & .003 & .718 & 1.108 \\
\hline SF1.4<-5EF1 & .714 & .081 & $<.001$ & .724 & .003 & .558 & .926 \\
\hline SF1.5<-SEF1 & .710 & .096 & $<.001$ & .716 & .004 & .519 & .940 \\
\hline SF2.2<-SEF2 & 1.482 & .283 & $<.001$ & 1.763 & .019 & 1.160 & 2.632 \\
\hline SF2.3<-SEF2 & .569 & .118 & $<.001$ & .562 & .004 & .358 & .814 \\
\hline SF2.4<-SEF2 & 1.252 & .239 & $<.001$ & 1.282 & .012 & .858 & 1.863 \\
\hline SF2.5<-SEF2 & 0.997 & .212 & $<.001$ & 1.022 & .010 & 0.632 & 1.565 \\
\hline PF1.2<-PPF & .885 & .178 & $<.001$ & .915 & .015 & .563 & 1.456 \\
\hline PF1.3<-PPF & .593 & .133 & $<.001$ & 609 & .007 & .378 & .914 \\
\hline $\begin{array}{l}\text { PF1.4<-PPF } \\
\end{array}$ & .464 & .128 & $<.001$ & .473 & .007 & .228 & .791 \\
\hline BP1.2<-BPF & .973 & .032 & $<.001$ & .975 & .001 & .912 & 1.040 \\
\hline BP1.3<-BPF & .749 & .037 & $<.001$ & .749 & .001 & .674 & \begin{tabular}{|l|}
.824 \\
\end{tabular} \\
\hline BPF<-MTF1 & 0.000 & & & 0.000 & & & \\
\hline BPF $<-$ MTF2 & .627 & .248 & .012 & .621 & .012 & .114 & 1.182 \\
\hline BPF<-MTF3 & .201 & .079 & .011 & .187 & .004 & .036 & .342 \\
\hline BPF $<-$ SEF1 & 0.000 & & & 0.000 & & & \\
\hline BPF $<-$ SEF2 & 0.000 & & & 0.000 & & & \\
\hline $\mathrm{BPF}<-\mathrm{PPF}$ & 0.000 & & & 0.000 & & & \\
\hline BPF<-BEFl & -.630 & .238 & .008 & -.618 & .007 & -1.097 & -.146 \\
\hline BPF $<-$ BEF2 & 0.000 & & & 0.000 & & & \\
\hline
\end{tabular}

\section{Concluding Remarks}

Immigrant entrepreneurs have emerged as key engines of growth for cosmopolitan cities and, with a little support, they could provide an even bigger economic boost in the future. So, how can we describe the differences in selfemployment rates? In the research field of immigrant and ethnic entrepreneurship there have been a variety of theories or explanations for rates of entrepreneurship among immigrants. One major reason for the wide variation in entrepreneurial appetite is that individuals who emigrate from some more developed countries tend to arrive with financial assets, high levels of educational attainment, and professional experience, while those who move here from other less developed countries are more likely to be poor, uneducated, and inexperienced in business matters. Cultural experiences also explain some of the differences in self-employment rates. For instance, researchers have found that some immigrant groups were particularly successful in starting businesses because they brought with them a tradition of using rotating credit associations to overcome financing obstacles. In contrast, other cultures frown upon taking loans and going into debt. Another factor that might help to explain why some immigrant communities start businesses at higher rates than others is that some countries from which immigrants hail have stronger or weaker traditions of entrepreneurship. 
The primary goal of this study is to assess the impact of several fundamental factors on the economic performance of second-generation migrant entrepreneurs. Our study analyses the main factors that have an impact on the economic performance of second-generation migrant entrepreneurs in the high-tech sector in four large cities in the Netherlands: Amsterdam, Rotterdam, Utrecht, and The Hague. The sample of our study consists of entrepreneurs of predominantly Turkish origin, and also a few of Moroccan Surinamese and Antillean origin, who are active in the advanced producer services (e.g. ICT,FIRE, and tourism services), and knowledge-intensive business services (KIBS) that all require highly-educated and skilled labour. A more detailed presentation of the ethnic composition of our sample and its distribution in the four biggest Dutch cities is beyond the scope of this article, but is included in another more descriptive study (see Sahin et al., 2012).

Ultimately, our structural equation model (SEM) shows that three of the eight hypothesized paths were statistically significant at a .05 probability level. Of the three significant paths, only the paths between social networks (MTF2) and pull factors (MTF3) had the direction predicted, while current business location (BEF1) and Business Performance showed a reverse relationship.

The constrained model, which showed better fit indices than the full model, indicated a rejection of most of the proposed hypotheses, since maintaining only three of the eight hypotheses did not result in a deterioration of model fit criteria. The results suggest no significant relationship between the Socio-economic Contextual Factors \{SEF1and SEF2) and Business Performance, whereas the ordered logit model suggests that a relationship between access to new markets (SEF2) and Business Performance exists. However, the results for the ordered logit model were mixed, and our SEM gives no evidence for this relationship. Therefore, Hypotheses $\mathrm{H} 3 \mathrm{a}$ and $\mathrm{H} 3 \mathrm{~b}$ are rejected based on the data. While previous studies have suggested a significant positive impact of innovation and business culture in general (e.g. Casson, 1994; Chakrabarti, 1990; Deeds and Rothaermel, 2003), this study indicates a lack of relationship between, on the one hand, the use of the Internet with lower transaction costs, training of employees and accessibility to new markets, and on the other hand, Business Performance.

Hypothesis $\mathrm{H} 4$ concerning the information gathering of entrepreneurs about public policies also appeared to be not significant in our structural equation model. In particular, concerning the effect of advice of a network organization and a consultant, the ordered logit model shows mixed evidence. Therefore, we conclude that, as far as our data are concerned, no connection can be established between the amount and sources of public policy information and the Business Performance indicators.

Of the three hypotheses with regard to Motivational Factors, two ( $\mathrm{H} 2 \mathrm{~b}$ and $\mathrm{H} 2 \mathrm{c}$ ) were found to be significant and positively related to Business Performance in both models. As such, our results support previous studies which have focused attention on Motivational Factors (e.g., Chrysostome and Arcand, 2009). Furthermore, the positive relationship between social networks and Business Performance adds to the notion that migrant entrepreneurs might be especially dependent on ethnic networks for business success. The acceptance of Hypothesis $\mathrm{H} 2 \mathrm{c}$, linking motivational pull factors to business success, can also be seen in the light of managerial performance, since the factor combines personal motivations with the ability to motivate others (Barney, 1991, 2001; Markman and Baron, 2003). Hypothesis H2a was not supported by the analysis, indicating no significant difference between entrepreneurs who were primarily motivated by factors such as poverty, unemployment or continuation of the family business, and those who were not.

Finally, of the two hypotheses about business location (HSa and HSb), only the current location significantly influenced Business Performance, while the start-up location had no clear effect. Contrary to the initial belief, home businesses reported a better Business Performance than businesses operating from offices outside the home. This might be linked with the earlier observation that migrant entrepreneurs seem more dependent on their local social network, which might be more accessible operating from the home environment.

While we have to acknowledge that not all model fit indices of our final model reached satisfactory levels, with an NFI (.0778) and PNFI (.698) lower than 0.9, a posterior predictive $p$ of 0.00 , and a significant $x^{2}$, it is a 
known problem that these indices are biased with small sample sizes, a large number of variables, and a nonnormal data distribution (Fan et al., 2011; Kenny and McCoach, 2003; Schumacker and Lomax, 2004). Since the better performing RMSEA and CFI indices both indicate a good model fit for the final model, the final parameter estimates can be considered as sufficiently stable. Comparing the estimates under both Maximum Likelihood and Bayesian estimation in Table 10, we observerthat the unstandardized factor weights are very similar between methods, However, as indicated by other authors (e.g. Mlndrila, 2010; Nevitt and Hancock, 2001), the standard errors of the Maximum Likelihood estimates are inflated under violations of multivariate normality and the inadequate measurement level. While this is not an issue in our analysis, it could potentially result in the rejection of certain parameter estimates and regression paths when used without caution.

\section{References}

Aldrich,H. and Waldinger,R. (1990). "Ethnicity and Entrepreneurship", Annual Review of Sociology, 16: 111-135.

Aldrich, H. and Martinez, M. (2001)."Many are Called, but Few are Chosen: An Evolutionary Perspective For The Study of Entrepreneurship", Entrepreneurship Theory \& Practice, 25:41-56.

Alsos, G.A., Isaksen, E.J. and ljunggren, E. (2006). "New Venture Financing and Subsequent Business Growth in Men- and Women-led Businesses",Entrepreneurship Theory \& Practice, 30(5): 667-88.

Antonelli,C.,(1998). localised technological change,new information technology and the knowledge-based economy: the European evidence, Journal of Evolutionary Economics, 8:177-198.

Amit, R., MacCrimmon, K., Zietsma, C. and Oesch, J. (2000). "Does Money Matter? Wealth Attainment as the Motive for Initiating GrowthOriented Technology Ventures",Journal of Business Venturing, 16(2):119-143.

Anand,B.N. and Khanna,T.(2000). "Do Firms learn to Create Value? The Case of Alliances",Strategic Management Journal, 21:295-315.

Arbuckle,J.I. (2009).Amos 18 User's Guide, Amos Development Corporation: Crawfordville,FI.

Atuahene-Gima, K. and Ko, A. (2001). "An Empirical Investigation of the Effect of Market Orientation Alignment on Product Innovation", Organization Science 12(1): 54-74.

Bailom,F., Matzler,K. and Tschemernjak,D. (2007). Enduring Success: What Top Companies Do Differently, Palgrave MacMillan: New York, NY. Barney,J. (1991). "Firm Resources and Sustained Competitive Advantage",Journal of Management, 17(1): 99-120.

Barney, J.B. (2001). "Resource-Based Theories of Competitive Advantage: A Ten-Year Retrospective on the Resource-Based View", Journal of Management, 27: 643-50.

Barrett,P. (2007) "Structural Equation Modeling: Adjudging model fit",Personality and Individual Differences, 42: 815-824.

Bates, T. (1990). "Entrepreneur Human Capital Inputs and Small Business longevity", The Review of Economics and Statistics, 72 (4): 551-9

Baycan-levent, T. and Nijkamp, P. (2009). "Characteristics of Migrant Entrepreneurship in Europe", Entrepreneurship \& Regional Development, 21(4):375-397.

Baycan-levent, T., Masurel, E. and Nijkamp, P. (2003). "Diversity in Entrepreneurship: Ethnic and Female Roles in Urban Economic life", International Journal Social Economic, 30(11): 1131-1161.

Baycan-levent,T.,Nijkamp, P. and Sahin, M. (2009). "New Orientations in Ethnic Entrepreneurship: Motivation, Goals and Strategies of New Generation Ethnic Entrepreneurs",International Journal Foresight and Innovation Policy, 5(1/2/3): 3-111.

Bhide,A.V. (2000). The Origin and Evolution of New Businesses, Oxford University Press:New York, NY.

Boden, R. and Nucci, A. (2000). "On the Survival Prospects of Men's and Women's New Business Ventures",Journal of Business Venturing, 15 (4): 347-62.

Borjas, G. J. (1999). Heaven's Door: Immigration Policy and the American Economy, Princeton University Press: Princeton, NJ.

Bowles, J. and Kotkin,J. (2003). "Engine Failure: With Economic Woes That Go Well Beyond 9/11, New York Needs a Bold New Vision to Renew the City's Economy",Center for an Urban Future.

Bruner,D.C. (2011). "Identifying and Comparing Characteristics of Successful Minority and Majority Businesses", McNair Chronicles, 3(1).

Bullvaag, E:, Allen, I. E., Bygrave, W. D. and Spinelli, S., Jr. (2006). Global Entrepreneurship Monitor, National Entrepreneurship Assessment, U.S.A.,2004-2005 executive report, Babson College: Wellesley,MA.

Byrne,B.M. (2010). Structural Equation Modeling with AMOS: Basic Concepts, Applications, and Programming, Routledge: New York.

Carrier, C., Raymond, I. and Eltaief, A. (2004). "Cyberentrepreneurship: A Multiple Case Study", International Journal of Entrepreneurial Behavior and Research, 10(5): 349-363.

Carter, N.M., Williams, M. and Reynolds,P.O. (1997). "Discontinuance among New Firms in Retail: The Influence of Initial Resources,Strategy, and Gender",Journal of Business Venturing, 12:125-45.

Cassar,G. (2004). "Entrepreneur Opportunity Costs and Intended Venture Growth",Journal of Business Venturing, 21(95):610-32.

Casson M. (1994). The Economics of Business Culture: Game theory, Transaction Costs and Economic Performance, Oxford University Press: New York.

Chakrabarti, A.K. (1990). "Scientific Output of Small and Medium Size Firms in High-Tech Industries", Engineering Management, IEEE Transactions, 48:52. 
Chrysostome, E. and Arcand, S. (2009). "Survival of Necessity Immigrant Entrepreneurs: An Exploratory Study", Journal of Comparative International Management, 12(2):3-29.

Chrysostome,E. and Lin,X. (2010). "Immigrant Entrepreneurship: Scrutinizing a Promising Type of Business Venture",Thunderbird Internotionol Review, 52: 77-82.

Clark, K. and Drinkwater, S. (2000). "Pushed Out or Pulled In? Self-employment among Ethnic Minorities in England and Wales", Labour Economics, 7: 603-628.

Coniglio,N.D. (2008). "Making Migration Work for Europe".In: O. Neumaier,G. Schweiger and C. Sedmak (eds) Perspectives on Work.

Cox,C. and Jennings,R. (199S). "The Foundation of Success: The Development and Characteristics of British Entrepreneurs and Intrapreneurs", Leadership and Organizational Development Journal, 16(7): 4-9.

Curci, R. and Mackay, R. (2010). "Immigrant Business Enterprises: A Classification Framework Coualization and Test",Thunderbird International Business Review, 52:107-121.

Dafna, K. (2008). "Managerial Performance and Business Success: Gender Differences in Canadian and Israeli Entrepreneurs", Journal of Enterprising Communities: People and Places in the Global Economy, 2(4): 300-331.

Deeds, D.L. and Rothaermel, F.T. (2003). "Honeymoons and Liabilities: The Relationship Between Age and Performance in R\&D Alliances", Journal of Product Innovation Management, 20(6): 468-84.

Delft,H. van, Gorter,C. and Nijkamp, P. (2000). "In Search of Migrant Entrepreneurship Opportunities in the City: A Comparative Policy Study", Environment and Planning C: Government and Policy, 18:429-451.

Du Reitz,A. and Henrekson, M. (2000). "Testing the Female Underperformance Hypothesis",Small Business Economics, $14: 1$-10.

Duysters,G.M., de Man, A.P. and Wildeman,L. (1999). "A Network Approach to Alliance Management",European Management Journal, 17(2): 182-7.

Fairlie,R.W. (2008). Estimating the Contribution of Immigrant Business Owners to the U.S. Economy (SBA Office of Advocacy Research Summary No. 334), SBA:Washington,DC.

Fan, X., Thompson, B. and Wang, L. (2011). "Effects of Sample Size, Estimation Methods, and Model Specification on Structural Equation Modeling Fit Indexes",Structural Equation Modeling: A Multidisciplinary Journal, 6(1): 56-83.

Field,A. (2000). Discovering Statistics Using SPSSfor Windows. SAGE Publications: London.

Filatotchev, 1., Liu X., Lu, J. and Wright, M. (2011). "KhOwledge Spillovers through Human Mobility Across National Borders: Evidence from Zhongguancun Science Park in China", Research Policy, 40(3):453-462.

Flamholtz, E. and Randle,Y. (2000). Growing Pains: Transitioning from an Entrepreneurship to a Professionally Managed Firm, Jossey-Bass: San Francisco, CA.

Florida, R. (2002). The Rise of the Creative Class, Basic Books: New York,NY

Freitas,G. de (1991). Inequality at Work: Hispanics in the US Labor Force, Oxford University Press: New York, NY.

Gagnon, Y.C.,Sicotte,H. and Posada, E. (2000), "Impact of SME Manager's Behavior on the Adoption of Technology", Entrepreneurship Theory \& Practice, 25(2): 43-58

Gao,S., Mokhtarian,P. L. and Johnston,R. A. (2008). "Nonnormality of Data in Structural Equation Models", Transportation Research Record, 2082: 116-124

Garson, G.D. (2011). Structural Equations Modeling, from Statnotes: Topics in Multivariate Analysis. Retrieved from http://www2.chass.ncsu.edu/garson/pa765/statnote.htm

Gigerenzer,G. (2010). "Moral Satisficing:Rethinking Moral Behavior as Bounded Rationality", Topics in Cognitive Science, 2:528-554.

Greiner, L.E. (1998). "Evolution and Revolution as Organizations Grow",Harvard Business Review, 76(3): 55-64.

Grilo,I. and Irigoyen,J.M. (2006). "Entrepreneurship in the EU:To Wish and Not To Be",Small Business Economics, 26(4): 305-18.

Guerrieri,P. and Meliciani, V. (2005). Technology and International Competitiveness:The Interdependence between Manufacturing and Producer Services,Structural Change and Economic Dynamics, 16: 489-502.

Hair,J.F.,Anderson,R.E.,Tatham,R.L. and Black,W.C. (1998). Multivariate Data Analysis, Prentice Hall: Upper Saddle River.

Hall,R. (1992). "The Intangible Analysis of Strategic Resources",Strategic Management Journal, 13:135-44.

Hart, D.M., Acs, ZJ. and Tracy, S.L., Jr. (2009). High-tech Immigrant Entrepreneurship in the United States, U.S. Small Business Administration Office of Advocacy: Washington,DC

Hart,D.M. and Acs,Z.J. (2011). "High-tech Immigrant Entrepreneurship in the U.S.", Economic Development Quarterly, 25:116-129.

Haas,de H. (2010). "Migration and Development: A Theoretical Perspective",International Migration Review, 44(1): $227-64$.

Hertog, den, P. (2000). Knowledge-intensive Business Services as Co-producers of Innovation,International Journal of Innovation Management, 4(4): 491-528.

Hisrisch,R. D., and Peters,M.P.(1989).Entrepreneurship: Starting, developing, and managing a new enterprise. Homewood,IL: Irwin

Hisrich, R.D. and Gracher,M.V. (1995). "The Russian Entrepreneur: Characteristics and Prescription for Success",Journal of Managerial Psychology, 10(2):3-9.

Ho,C. and Li,D.(2006).Spatial analysis of city income distribution dynamics in China. Paper presented at the Chinese Economists Society 2006 Annual Conference.

Hodgetts,R.M. and Kuratko, D.F. (1992). Effective Small Business Management, Harcourt Brace Jovanovich:San Diego, FL.

Ibrahim,G.and Galt,V.(2011). "Explaining Ethnic Entrepreneurship: An Evolutionary Economics Approach",International Business Review.

Johannisson, B. (2000). "Networking and Entrepreneurial Growth". In: D.L. Sexton and H. Landstrom (eds), The Blackwell Handbook of Entrepreneurship, Blackwell: Oxford.

Jong,J.P J. and Hartog, D.N.D. (2007). "How Leaders Influence Employees' Innovative Behavior",European Journal of Innovation Management, 10(1): 41-64

Jiireskog,K.G., and Siirbom,D. (1996).L/SREL 8: User's Reference Guide, Scientific Software International: Chicago.

Kalleberg, A.L. and Leicht, K.T. (1991). "Gender and Organizational Performance: Determinants of Small Business Survival and Success", Academy of Management Journal, 34(1):136-61. 
Kapur,D. \{2003). "Remittances: The New Development Mantra", Paper prepared for the G-24 Technical Group Meeting.

Kenny, D.A. and McCoach, B.D. \{2003). "Effect of the Number of Variables on Measures of Fit in Structural Equation Modeling", Structural Equation Modeling: A Multidisciplinary Journal,10\{3): 333-351.

Kirzner,I.M. \{1973). Competition and Entrepreneurship, University of Chicago Press:Chicago,IL.

Kline,R.B.(2010). Principles and Practice of Structural Equation Modeling. Third Edition, Guilford Press: New York.

Kloosterman, R. and Rath, J. (2001). "Immigrant Entrepreneurs In Advanced Economies: Mixed Embeddedness Further Explored", Journal of Ethnic and Migration Studies, 27(2): 189-202.

Kubinger K.D. \{2003). "On Artificial Results Due to Using Factor Analysis For Dichotomous Variables",Psychology Science, 45\{1): 106-110.

Kuratko,D.F. and Hodgetts, R.M. \{2004). Entrepreneurship: Theory, Process \& Practice, South-Western Publishers: $\mathrm{Mason}, \mathrm{OH}$.

Light,I.H. and Rosenstein, C.N. \{1995). Race, Ethnicity, and Entrepreneurship in Urban America, Aldine de Gruyter: New York, NY.

Light,I. and Bonacich,E.(1988).1mmigrant Entrepreneurs: Koreans in Los Angeles 1965-1982, University of California Press:Berkeley,CA.

Lee,S.Y. and Song X.Y. \{2003). "Bayesian Analysis of Structural Equation Models With Dichotomous Variables",Statistics in Medicine, 22:30733088.

Makhbul, Z.M. \{2011\}. "Entrepreneurial Success: An Exploratory Study among Entrepreneurs", International Journal of Business and Management, 6\{1):116-125.

March,J.G. (1978). "Bounded Rationality,Ambiguity,and the Engineering of Choice",Bell Journal of Economics, 9: 587-608.

Ma;czyk,D., DeMatteo, D. and Festinger, D. \{2005). Essentials of Research and Design Methodology. John Wiley \& Sons: New York,NY.

Markman, G. and Baron, R. (2003). "Person-Entrepreneurship Fit: Why Some People Are More Successful as Entrepreneurs than Others", Human Resource Management Review, 13\{2): 281-301.

Marlow, S. (1992\}. "The Take-up of Business Growth Training Schemes by Ethnic Minority-owned Firms in Britain",International Small Business Journal, 10\{4): 34-47.

McClelland,D.C. \{1961). The Achieving Society, D. Van Norstrand Co. Inc: New York, NY,pp. 210-215.

Meredith,G.G., Nelson, R.E. and Neck,P.A. \{1982). "The Practice of Entrepreneurship",Geneva International Labour Office: Switzerland. Merenda,

P.F. \{1997). "A Guide to the Proper Use of Factor Analysis in the Conduct and Reporting of Research:Pitfalls to Avoid",Measurement and Evaluation in Counseling and Development, 30:156-164.

Minetti, M., Allen, E. and Langowitz, N. (2006). GEM: Report and Women and Entrepreneurship, Global Entrepreneurship Monitor, a joint publication ofThe Center for Women's Leadership at Babson College and the London School of Business.

MIndrila, D. (2010). "Maximum Likelihood (ML) and Diagonally Weighted Least Squares \{OWLS) Estimation Procedures: A Comparison of Estimation Bias with Ordinal and Multivariate Non-Normal Data",International Journal of Digital Society, 1(1): 60-66.

Mulaik, S.A. and Millsap, R.E. \{2000). "Doing the Four-step Right", Structural Equation Modeling, 7:36-73.

Muthen, B. and Kaplan, D. \{1985). "A Comparison of Methodologies for the Factor Analysis of Non-Normal Likert Variables", British Journal of Mathematical and Statistical Psychology, 38\{1):171-189.

Nandram, S.S. \{2002). "Attributes of Entrepreneurial Success and Failures. New Perspectives gained from the Critical Incident Technique", in Conference Proceedings. The 2002 Small Business and Entrepreneurship Development Conference, The University of Nottingham: UK.

Ndofor, A.H. and Priem, R.L. \{2011). "Immigrant Entrepreneurs, the Ethnic Enclave Strategy, and Venture Performance", Journal of Management, 37\{3): 79Q-818.

Neelankavil,J., Mathur, A. and Zhang, Y. \{2000). "Determinants of Managerial Performance: A Cross-cultural Comparison of the Perceptions of Middle-level Managers in Four Countries",Journal of International Business Studies, 31\{1),121-140.

Nevitt, J. and Hancock, G.R. \{2001). "Performance of Bootstrapping Approaches to Model Test Statistics and Parameter Standard Error Estimation in Structural Equation Modeling",Structural Equation Modeling: A Multidisciplinary Journal, 8\{3):353-377.

Perren,L. \{1999). "Factors in the Growth of Micro-enterprises: Developing a Framework,Journal of Small Business and Enterprise Development, 6\{4): 366-385.

Portes,A. and Rumbaut,R. (1996).1mmigrant America: A Portrait, University of California Press: Berkley,CA.

Rath,J.(2000). "Introduction; Immigrant Business and the Economic, Politico-Institutional and Social Environment". In: J. Rath (ed.),Immigrant Business: The Economic, Political and Social Environment, Macmillan Press: London, pp.1-19.

Ratha, D., Mohapatra,S. and Scheja, E. (2010). "Impact of Migration on Economic and Social Development: A Review of Evidence and Emerging Issues", World Bank Policy Research Working Paper No.5558.

Rotter, J.B. (1966). "Generalized Expectations For Internal Versus External Control of Reinforcement", Psychological Monographs: General and Applied, 80\{1): 1-27.

Rusinovic, K. \{2008) "Moving Between Markets? Immigrant Entrepreneurs in Different Markets", International Journal of Entrepreneurial Behaviour \& Research, 14(6): 440-454.

Sahin, M., Todiras, A., Nijkamp,P. and Masurel, E. (2011a). "An Explanatory Model for the Economic Performance of Migrant Entrepreneurs in the High-tech Sector".In:P. Nijkamp,J. Poot and M. Sahin (eds), Migration Impact Analysis: New Horizons \{forthcoming).

Sahin, M., Todiras, A., Nijkamp,P. and Suzuki,S. (2011b). Migrant Impact Assessment of Ethnic Entrepreneurs: Data Envelopment Analysis as a Policy Support Tool,Innovation (forthcoming).

Sahin,M., Todiras, A., and Nijkamp,P. \{2012\}. Colourful Entrepreneurship in Dutch Cities:A Review and Analysis of Business Performance, Regional Science Inquiry, 3 (accepted for publication).

Saunders,M.,Lewis, P. and Thornhill, A. (2006). Research Methods For Business Students, Prentice Hall: Harlow.

Say, J.B. \{1971). A Treatise on Political Economy or the Production, Distribution and Consumption of Wealth. A.M. Kelley Publishers: New York, NY.

Schumacker, R.E. and Lomax,R.G. \{2004). A Beginners Guide to Structural Equation Modeling, Lawrence Erlbaum Associates:New Jersey.

Sethi, V. and King, W. R. \{1994). "Development of Measures to Assess the Extent to Which an Information Technology Application Provides Competitive Advantage",Management Science, 40\{12\}:1601-1627. 
Sexton, D.L. and Bowman-Upton, N. (1990). "Female and Male Entrepreneurs: Psychological Characteristics and Their Role in Gender Related Discrimination",Journal of Business Venturing, 5(1): 29-36.

Shane, S. and Venkataraman, S. (2000). "The Promise of Entrepreneurship as a Field of Research", Academy of Management Review, 25: 217226.

Sharma,S. (1996). Applied Multivariate Techniques, John Wiley \& Sons: New York.

Silvia,E.S.M. and MacCallum, R.C. (1988). "Some factors affecting the success of specification searches in covariance structure modeling", Multivariate Behavioral Research, 23:297-326.

Smallbone, D., Bertotti, M. and Ekanem, I. (2005). "Diversification in Ethnic Minority Business: The Case of Asians in London's Creative Industries", International Journal of Entrepreneurial Behaviour \& Research,12(1): 41-56.

Steensma, H.K., Marino, L. and Dickson, P.H. (2000). "The Influence of National Culture on the Formation of Technology Alliances by Entrepreneurial Firms, Academy of Management Journal,43(5),951-973.

Swiercz,P.M. and Lydon, S.R. (2002). "Entrepreneurial Leadership in High-tech Firms: A Field Study", Leadership and Organization Development Journal, 23(7): 380-389.

Tabachnick, B.G. and Fidell,L.S. (1996). Using Multivariate Statistics. HarperCollins: New York, USA. Train, K.

(2003). Discrete Choice Models With Simulation, Cambridge University Press: Cambridge. Tzilivakis, K.

(2005). Athens News Online,ATHENS NEWS, 26/08/2005,page:A15, Article code: C13145A151.

Wadhaw,R.K. (1998). Entrepreneur and Enterprise Management, Karishka Publisher: India.

Waldinger,R. (1986). "Immigrant Enterprise",Theory and Society,15(1-2): 249-285.

Walter, A., Auer, M. and Ritter, T. (2006). "The Impact of Network Capabilities and Entrepreneurial Orientation on University Spin-Off Performance", Journal of Business Venturing, 21(4):541-67.

Wang, Q. (2010). "Immigration and Ethnic Entrepreneurship: A Comparative Study in the United States",Growth and Change, 42(3): 430-450.

Watson, K., Horgarth-Scott, S. and Wilson, N. (1998). "Small Business Start-Ups: Success Factors and Support Implication", Journal of Entrepreneurial Behaviour and Research,4(3): 217-238.

Watson,J. (2006), "External Funding and Firm Growth: Comparing Female- and Male-Controlled SME's",Venture Capital, 8(1): $33-49$.

Weitzman, M. and Kruse,D.L. (1990). "Profit Sharing and Productivity". In: A.S. Blinder (ed.), Paying for Productivity. A Look at the Evidence, Brookings Institution: Washington,DC.

Wothke, W. (1993). Nonpositive Definite Matrices In Structural Modeling, In:K.A.Bollen and J.S. Long (eds), Testing structural equation models, Sage Publications: Newbury Park,CA, pp. 256-293.

Wright, K. and Black, R. (2011). "International Migration and the Downturn: Assessing the Impacts of the Global Financial Downturn on Migration, Poverty and Human Well-being",Journal of International Development, 23(4): 555-564.

Yin,R.K. (1989). Case study research: Design and methods, SAGE Publications: London.

Yung, Y.F. and Bentler, P.M. (1994). "Bootstrap-corrected ADF Test Statistics In Covariance Structure Analysis", British Journal of Mathematical and Statistical Psychology, 47:63-84.

Zahra,S.A. (2007). "Contextualizing Theory Building in Entrepreneurship Research",Journa/ of Business Venturing, $22(3)$ : $443-52$.

Zaiceva,A. and Zimmermann, K. (2008). "Scale, Diversity, and Determinants of Labour Migration in Europe",Oxford Review of Economic Policy, 24(3): 427-451.

Zenger, T.R. (1992). "Why do Employers Only Reward Extreme Performance? Examining the Relationships among Performance, Pay, and Turnover", Administrative Science Quarterly,37:198-219.

Zou, M. and Kim, S. (2006). "Community Forces, Social Capital and Educational Achievement: The Case of Supplementary Education in the Chinese and Korean Immigrant Communities", Harvard Educational Review, 76(1): 1-29. 
